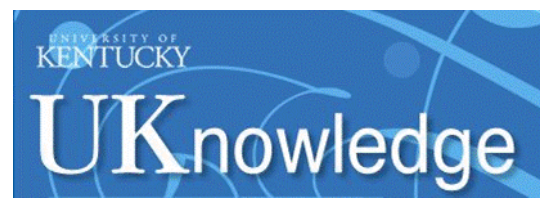

University of Kentucky

UKnowledge

Spring 2007

\title{
Managers' Fiduciary Duties in Financially Distressed Corporations: Chaos in Delaware (and Elsewhere)
}

Rutheford B. Campbell Jr.

University of Kentucky College of Law, rcampbel@uky.edu

Christopher W. Frost

University of Kentucky College of Law, cfros1@uky.edu

Follow this and additional works at: https://uknowledge.uky.edu/law_facpub

Part of the Bankruptcy Law Commons, and the Business Organizations Law Commons

Right click to open a feedback form in a new tab to let us know how this document benefits you.

\section{Recommended Citation}

Rutheford B Campbell, Jr. \& Christopher W. Frost, Managers' Fiduciary Duties in Financially Distressed Corporations: Chaos in Delaware (and Elsewhere), 32 J. Corp. L. 491 (2007).

This Article is brought to you for free and open access by the Law Faculty Publications at UKnowledge. It has been accepted for inclusion in Law Faculty Scholarly Articles by an authorized administrator of UKnowledge. For more information, please contact UKnowledge@lsv.uky.edu. 
Managers' Fiduciary Duties in Financially Distressed Corporations: Chaos in Delaware (and Elsewhere)

\section{Notes/Citation Information}

The Journal of Corporation Law, Vol. 32, No. 3 (Spring 2007), pp. 491-525 


\title{
Managers' Fiduciary Duties in Financially Distressed Corporations: Chaos in Delaware (and Elsewhere)
}

\author{
Rutheford B. Campbell, Jr. \\ Christopher W. Frost ${ }^{* *}$
}

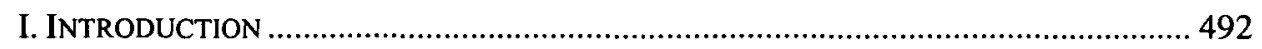

II. Positive ANALYSIS OF CoRPORATE FiducIaRy DUtIES......................................... 495

A. In Normal or Solvent Periods ........................................................................ 495

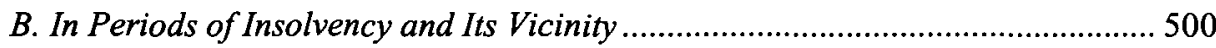

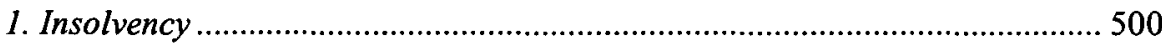

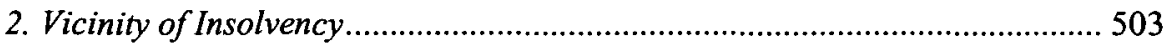

C. Bankruptcy Court's Interpretations of Managers' Duties Before Bankruptcy:

Weiboldt Stores, Inc. v. Schottenstein .......................................................... 506

D. Duties of Corporate Managers in Bankruptcy Cases........................................ 508

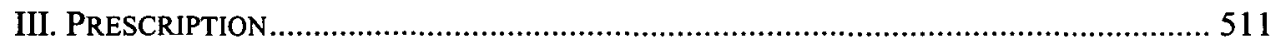

A. The Normative Justifications for Shareholder Wealth Maximization .................. 512

1. Criterion for Efficiency Analyses of Corporate Governance Regimes .......... 513

2. Shareholder Wealth Maximization and the Efficiency Criterion .................... 513

B. Fiduciary Duties in and near Insolvency ....................................................... 517

1. Normative Justifications for the Shift of Duty upon and in the

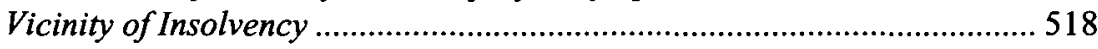

2. Critique of the Shift in Duties .................................................................... 519

C. The Exception: Manager Fiduciary Duties in Bankruptcy................................. 522

IV. CONCLUSION ................................................................................................. 525 


\section{INTRODUCTION}

The inherent conflict between creditors and shareholders' has long occupied courts and commentators interested in corporate governance. ${ }^{2}$ Creditors holding fixed claims to the corporation's assets generally prefer corporate decision making that minimizes the risk of firm failure. Shareholders, in contrast, have a greater appetite for risk, because, as residual owners, they reap the rewards of firm success while sharing the risk of loss with creditors. ${ }^{3}$

Traditionally, this conflict is mediated by a governance structure that imposes a fiduciary duty on the corporation's managers-its officers and directors-to maximize the value of the shareholders' interests in the firm. ${ }^{4}$ In this traditional view, officers, and directors serve as agents of the shareholders and thus are charged with a fiduciary duty to maximize the value of the principals' ownership interests. Under this model of corporate governance, managers are not agents for the company's creditors and thus owe no fiduciary duty to act in the best interests of creditors. ${ }^{5}$

Alumni Professor of Law, University of Kentucky College of Law.
"Frost, Brown, Todd Professor of Law, University of Kentucky College of Law.

1. Some of the best work in this area occurred in the period during and following the spate of highly leveraged acquisitions of the 1980s. See, e.g., William W. Bratton, Jr., Corporate Debt Relationships: Legal Theory in a Time of Restructuring, 1989 Duke L.J. 92 (1989); Morey W. McDaniel, Bondholders and Stockholders, 13 J. CORP. L. 205 (1988); Morey W. McDaniel, Bondholders and Corporate Governance, 41 BUS. LAW 413 (1986); Lawrence E. Mitchell, The Fairness Rights of Corporate Bondholders, 65 N.Y.U. L. REV. 1165 (1990). Commentators also provided an empirical look at the impact of leveraged transactions of the 1980s. See Thomas R. Hurst \& Larry J. McGuinness, The Corporation, The Bondholder and Fiduciary Duties, 10 J.L. \& COM. 187, 190 n.14 (1991) (reporting that between 1984 and 1989, more than 230 companies were involved in transactions that caused a downgrading of their debt instruments); Marcel Kahan \& Michael Klauser, Antitakeover Provisions in Bonds: Bondholder Protection or Management Entrenchment?, 40 UCLA L. REV. 931, 933 \& n.2 (1993) (reporting that between 1984 and 1988, "mergers, acquisitions or leveraged buyouts" caused the bonds of 183 companies to lose value); see also Rutheford B. Campbell, Jr., $A$ Positive Analysis of the Common Law of Corporate Fiduciary Duties, 84 KY. L.J. 455, 460-69 (1995-96) (demonstrating the conflicts among shareholders, creditors and other corporate constituencies and the impact of managerial actions on the various corporate constituencies).

2. See Lynn A. Stout, Bad and Not-So-Bad Arguments for Shareholder Primacy, 75 S. CAL. L. REV. 1189 (2002) (describing the academic debate between Professors Berle and Dodd during the 1930s).

3. Consider the following simple example. Assume a corporation has a value of 100 , which is represented by 50 in debt and 50 in equity. The corporation has an opportunity to reinvest its assets in a way that has a $50 \%$ chance of achieving a value of 200 and a $50 \%$ chance of achieving a value of 0 . Creditors, as a result of the reinvestment will have an expected value of 25 , which consists of a $50 \%$ chance of $0(=0)$ and a $50 \%$ chance of $50(=25$ (because of their fixed obligation, if the company achieves a value of 200 , creditors still receive only 50)). Shareholders, however, have an expected reinvestment value of 75 , which is a $50 \%$ chance of 0 and a $50 \%$ chance of 150 (if the company achieves a value of 200 , shareholders are entitled to 200 minus the 50 claims of creditors).

4. See, e.g., Henry Hansmann \& Reinier Kraakman, The End of History for Corporate Law, 89 GEO. L.J. 439, 468 (2001) (noting that managers have "duties to serve the interests of shareholders alone .. ."); Roberta Romano, A Cautionary Note on Drawing Lessons from Comparative Corporate Law, 102 YALE L.J. 2021, 2031 (1993) (explaining that U.S. corporation law seeks to "maximize shareholder welfare").

5. Although one is able to find occasional cases affording creditors fiduciary or fiduciary-like protections, see, e.g., Swinney v. Keebler Co., 329 F. Supp. 216 (D.S.C. 1971, rev'd on other grounds, 480 F.2d 573 (4th Cir. 1973), such cases are aberrational and inconsistent with the long standing, see, e.g., HENRY W. BALlantine, BALlantine ON CORPORATIONS 184 (Rev. Ed. 1946) ("Creditors have no direct right of action against directors or officers for mismanagement . . by the better view.") and widely held rule that mangers owe 
For the most part, this traditional model of corporate governance has dominated corporate law. ${ }^{6}$ Over recent years, however, a number of courts have suggested or held that these normal fiduciary duties of corporate managers may change when firms move into and through periods of deepening financial distress.

Courts have staked out at least four separate periods as a company moves across a spectrum from financial solvency to bankruptcy. The first period along the spectrum is the normal or solvent period for the corporation. ${ }^{7}$ Next is a period when the corporation is not yet insolvent but is close to insolvency. Sometimes this period is called the "vicinity of insolvency" or the "zone of insolvency." $8 \mathrm{Next}$, as conditions continue to deteriorate, is a period in which the corporation is insolvent but has not yet filed for bankruptcy. ${ }^{9}$ Finally, the fourth period commences when the corporation files a bankruptcy petition and, we assume, begins reorganization under Chapter $11 .{ }^{10}$

While generally across this time spectrum courts define fiduciary duties as an obligation to maximize some "value," the question of whose value is to be maximized in any given period is uncertain. Three possible beneficiaries of managers' value maximization obligation have emerged from the cases. The beneficiaries may be: (1) shareholders; (2) creditors; or (3) the "corporation", which should be interpreted as some combination of corporate stakeholders. The cases hold or suggest that the obligation of corporate managers in normal or solvent periods is to act in the best interests of shareholders ${ }^{11}$ but that the duty changes to an obligation to act in the best interests of the corporation once the firm enters the vicinity of insolvency. ${ }^{12}$ As the firm's financial distress deepens and it passes out of the vicinity of insolvency and into actual insolvency, cases suggest or hold that the obligation of managers becomes a duty to maximize the interests of creditors. ${ }^{13}$ Finally, when the company enters bankruptcy and is operating under Chapter 11, the cases hold or suggest that the obligation is to maximize the total interests of creditors and shareholders as a whole. ${ }^{14}$

creditors no fiduciary duties. See, e.g., Metro. Life Ins. Co. v. RJR Nabisco, Inc., 716 F. Supp. 1504 (S.D.N.Y. 1989) (no fiduciary duties owed to bondholders); Skinner v. Hulsey, 138 So. 769, 773 (Fla. 1931) ("Directors are not liable to the creditors on the theory of their being fiduciaries."); Whitfield v. Kern, 192 A. 48, 55 (N.J. 1937) (management is not the agent for creditors); Confick v. Houston Civic Opera Ass'n, 99 S.W.2d 382, 385 (Tex. 1936) ("Directors are not personally liable to creditors for mismanagement, or for waste of assets except on proof of the commission of actual fraud.").

6. While not arguing that directors owe any affirmative duty to act in the best interests of nonshareholder constituencies, a recent line of scholarship argues that directors are not obliged to act in the best interests of shareholders. This line of scholarship interprets modern corporate law as giving "directors free rein to pursue strategies that reduce shareholder wealth while benefiting other constituencies." Stout, supra note 2, at 1202. At another point in her piece, Professor Stout states that "corporate law . . generally allows directors to redirect wealth from shareholders to other stakeholders." Id. at 1203. As a positive matter, we reject this interpretation and side with the traditional view that managers owe duties to the owners of corporations. See infra notes 17-39 and accompanying text.

7. See infra notes 17-39 and accompanying text.

8. See infra notes 55-72 and accompanying text.

9. See infra notes 40-79 and accompanying text.

10. See infra notes 80-95 and accompanying text.

11. See infra notes 17-27 and accompanying text.

12. See infra notes 55-60 and accompanying text.

13. See infra notes 51-54 and accompanying text.

14. See infra notes 83-86 and accompanying text. 
This line of cases is rife with uncertainties. Defining the perimeters of the periods is often difficult. An obligation to act in the best interests of the "corporation" raises the question of which of the corporate stakeholders or constituencies (e.g., employees, the community) are included in the "corporation." Is the obligation of corporate managers to act in the best interests of the preferred constituency (e.g., creditors) unbending, or is it permissible for managers to pursue a path that benefits a non-favored constituency (e.g., shareholders) at the expense of the favored constituency (e.g., creditors)? If managers are permitted to pursue such a path, is there a limit on the extent of the permissible sacrifice managers may visit on the favored constituency?

These shifting duties and the accompanying uncertainties cause problems for managers attempting to live up to their legal obligations. Even more important to us, however, is the pernicious impact that such confusion has on the pricing of capital and the allocation of risks among investors. When shareholders and creditors contribute their capital to a corporation, they price their investment and shape the terms of their contract in part by reference to fiduciary duties and the extent to which they are the beneficiaries of managers' fiduciary obligations. ${ }^{15}$ Confusion and complexity respecting the matter of whose value in what period managers are obliged to maximize make it nearly impossible for investors-shareholders and creditors-to price the capital they contribute to the corporation and to allocate the risk of loss in corporate transactions to the most efficient bearer of that risk. ${ }^{16}$

The purpose of this Article is twofold. First, we offer a positive analysis of the fiduciary duties of managers, as corporations move along the time spectrum from solvency to Chapter 11 reorganization. While, certainly, we are unable to clarify entirely the mess that courts have created, we believe that we are able to offer guidance regarding the present state of the law and how the law is likely to evolve on these important matters.

In the second part of the Article, we offer our prescription for corporate managers' fiduciary duties, as corporations move along the time spectrum from solvency to bankruptcy. Our view is that the fiduciary obligation of corporate managers should be uniform across the pre-bankruptcy period, changing only at the point the company enters into Chapter 11. Our prescription is informed by simple economic concepts. Our view is that clear and efficient default rules are of the utmost importance, since such rules will protect the expectations of the parties, respect their pricing, and thus facilitate an efficient allocation of the risk of loss in financial transactions.

15. A classic example is a provision in a loan agreement limiting the amount of dividends that can be distributed to shareholders. Without such a covenant, managers may have an incentive to pay large dividends to shareholders, making it less likely that the company can repay creditors according to the terms of their loan contract.

16. The court's opinion in Metro. Life Ins. Co. v. RJR Nabisco, Inc., 716 F. Supp. 1504, 1516 (S.D.N.Y. 1989), is interesting in this regard, since it affirms a view of fiduciary duties during normal or solvent periods that enable investors - shareholders and creditors-to price their capital they contribute and allocate risk among various investors. In that case, bondholders argued that an implied term in their contract and fiduciary duties prevented RJR from assuming additional debt that depreciated the market value of the plaintiffs' bonds. In rejecting these claims, the court pointed out that the plaintiffs were some of the most sophisticated lenders in the country and had relinquished covenants that would have protected them from the adverse effects of additional leverage. In short, the court concluded that these very sophisticated lenders had assumed and priced the risk of additional leverage by RJR. 


\section{Positive ANALYSis of CoRPorate FiduCIARY Duties}

\section{A. In Normal or Solvent Periods}

In normal times-before a company enters bankruptcy or otherwise gets itself in a situation of financial distress-the fiduciary duties of corporate managers are often articulated by reference to the best interests of "the corporation." 17 Notwithstanding such language, it is generally conceded that corporate managers are under a duty to act in the best interests of the company's shareholders, ${ }^{18}$ a duty that is often stated in terms of an obligation to maximize shareholder wealth. ${ }^{19}$

A corollary of this fiduciary duty to act in the best interests of shareholders is that corporate managers owe no fiduciary duty to the corporation's creditors ${ }^{20}$ or any other

17. For example, in their fine treatise, James Cox and Thomas Hazen state that "[w]hen directors or officers are guilty of mismanagement or negligence in conducting corporate affairs, the right of action is primarily in the corporation ... ." JAMES D. COX \& THOMAS LEE HAZEN, CORPORATIONS 217 (2d ed. 2003). The authors go on to indicate that the managers' duties are defined by the interests of shareholders: "It is broadly recognized that the directors ... owe their fiduciary obligations to the corporation and its shareholders; creditors' rights are accordingly limited to the fair construction of a creditor's contract with the corporation." Id.

18. The fiduciary duties owed to shareholders are typically broken down into two components, the duty of care and the duty of loyalty. See, e.g., id. at 184-207. Under their duty of care obligation, corporate managers are obliged to act with a degree of care in regard to the maximization of shareholder wealth. The degree of care directors are required to observe may differ, depending on whether the directors are involved in monitoring or making discrete decisions. In monitoring, directors are most likely judged against a reasonableness or negligence standard. See, e.g., Francis v. United Jersey Bank, 432 A.2d 814, 821 (N.J. 1981). In cases involving discrete decisions-a decision to facilitate the sale of the company, for example-directors operating under the business judgment standard may be held liable only if their decision is so unreasonable as to amount to gross negligence. See, e.g., Aronson v. Lewis, 473 A.2d 805, 812 (Del. 1984) ("[U]nder the business judgment rule director liability is predicated upon concepts of gross negligence."). Whether the matter involves monitoring or a discrete decision, managers' duty of care is measured against the obligation to act in the best interests of shareholders.

19. See supra note 4 and accompanying text; see also Stephen M. Bainbridge, Director v. Shareholder Primacy in the Convergence Debate, 16 TRANSNAT'L LAW. 45, 48 (2002) (“Despite occasional academic arguments to the contrary, the shareholder wealth maximization norm . . . indisputably is the law in the United States."); ROBERT CLARK, CORPORATE LAW 678 (1986) (stating that "from the traditional legal viewpoint, a corporation's directors and officers have a fiduciary duty to maximize shareholder wealth, subject to numerous duties to meet specific obligations to other groups affected by the corporation"). A recent line of scholarship, developed in large part by Professors Margaret M. Blair and Lynn A. Stout, interprets the duties of managers somewhat differently from the traditional view. See Margaret M. Blair \& Lynn A. Stout, A Team Production Theory of Corporate Law, 85 VA. L. REV. 247 (1999). This view rejects any ubiquitous obligation on the part of directors to act in the best interests of shareholders, and instead argues that "corporate law . . . generally allows directors to redirect wealth from shareholders to other stakeholders." Stout, supra note 2, at 1203. According to Professor Stout, "Delaware gives directors free rein to pursue strategies that reduce shareholder wealth while benefiting other constituencies." Id. at 1202. The authority relied upon to support this position includes the right of corporations to make charitable contributions, court opinions in takeover cases that allow directors to consider the interests of non-shareholder constituencies, and state constituency statutes. See Blair \& Stout, supra, at 285; Stout, supra note 2, at 1201-07.

20. In addition to the cases cited in note 5, supra, the following cases are examples of decisions that support the lack of any managerial fiduciary duty to creditors: Pittsburgh Terminal Corp. v. Baltimore \& O.R.R. 680 F.2d 933, 941 (3d Cir. 1982), cert. denied, 459 U.S. 1056 (1982); Harff v. Kerkorian, 324 A.2d 215 (Del Ch. 1974), rev'd on other grounds, 347 A.2d 133 (Del. 1975); see also Lawrence Mitchell, supra note 1, at 1169 n.11 ("Scholars supporting expanded bondholder rights do not have a great deal of law supporting 
non-shareholder constituency, such as employees. ${ }^{21}$ Duties to creditors (and other nonshareholder constituencies) are purely contractual in nature, ${ }^{22}$ except for discrete legal duties imposed on the corporation (and its managers), such as duties to refrain from paying excessive dividends to shareholders ${ }^{23}$ or engaging in fraudulent transfers. ${ }^{24}$

To illustrate these basic points, consider an example roughly based on the $R J R$ Nabisco case. ${ }^{25}$ Target is acquired in a highly leveraged acquisition. It is an all cash deal at a price that amounts to a large premium over Target's market price. Shareholders as a whole are better off as a result of the acquisition. The additional leverage, however, causes a significant loss in the market value of Target's credit instruments.

Target's managers who facilitate this acquisition appear to be acting consistent with their obligation to maximize the wealth of Target's shareholders. It does not matter that part of Target shareholders' gain came at the expense of the company's creditors. Managers owe no broad fiduciary duty to act in the best interests of creditors. ${ }^{26}$ Target's

them.").

21. While as a positive matter, no one argues with the proposition that managers do not owe any fiduciary duty to act in the best interests of employees, some scholars have argued that employees are especially vulnerable to expropriative conduct by corporate managers operating in the best interests of shareholders. One argument is that employees make human capital investments in their firms and under-price their services in their early years with their firm in return for an implied promise from the firm to repay the employees in their late years. Firms may have an economic interest in breaching this implied promise. See Katherine Van Wezel Stone, Policing Employment Contracts with the Nexus-of-Contracts Firm, 43 U. TORONTO L.J. 353, 363-69 (1993) (explaining that "employees' value to their employer increases over time as they acquire firm-specific capital, while their value to other employers may not"); Katherine Van Wezel Stone, Employees as Stakeholders under State Nonshareholder Constituency Statutes, 21 STETSON L. REV. 45, 48-53 (1991); Marleen O'Connor, Restructuring the Corporation's Nexus of Contracts: Recognizing a Fiduciary Duty to Protect Displaced Workers, 69 N.C. L. REV. 1189, 1205-07 (1991) (explaining that firms may opportunistically breach such contracts). Predictably, other scholars argue that workers are fully capable of protecting their interests through contracts and pricing. See, e.g., Richard Epstein, In Defense of the Contract at Will, 51 U. CHI. L. REV. 947, 954 (1984) (stating that "people who are competent enough to marry, vote, and pray are not unable to protect themselves in their day-to-day business transactions"). Other scholars also point out that expropriation of employees' human capital investment may not be in the corporation's best interest. Clive Bull, The Existence of Self-Enforcing Implicit Contracts, 102 Q.J. ECON. 147, 149-54 (1987) (explaining that such exploitation creates morale problems for remaining workers); Jonathan R. Macey, Externalities, Firm-Specific Capital Investments, and the Legal Treatment of Fundamental Corporate Changes, 1989 DUKE L.J. 173, 192 (1989) (noting that an "employer's need to maintain its reputation in its community and to attract new workers in the future will tend to discourage exploitation").

22. See, e.g., Metro. Life Ins. Co. v. RJR Nabisco, Inc., 716 F. Supp. 1504 (S.D.N.Y. 1989) (refusing to find any implied term limiting the company's assumption of additional debt and refusing to extend any extracontractual protections to creditors); Katz v. Oak Indus. Inc., 508 A.2d 873, 879 (Del. Ch. 1986) (rejecting any duty to act in the best interests of creditors and stating that "if courts are to provide protection against such enhanced risk, they will require either legislative direction to do so or the negotiation of indenture provisions designed to afford such protection").

23. The Model Business Corporation Act imposes both a balance sheet and an insolvency test on a corporate board's right to pay dividends. MODEL BUS. CORP. ACT $\$ 6.40$ (c) (2005). This provision is designed to protect non-shareholder constituencies against payment of excessive dividends to shareholders.

24. 11 U.S.C. $\$ 548$ (2005); UNIF. FRAUDULENT TRANSFER ACT, 7A U.L.A. 643 (1984).

25. Metro. Life Ins. Co., 716 F. Supp. at 1504.

26. While one may imagine that most highly leveraged acquisitions are powered, at least to some degree, by efficiencies, see Campbell, supra note 1 , at $460-69$, it is conceivable that some acquisitions may be powered only by expropriation and indeed may even generate negative efficiencies or synergies. To use very simple numbers, assume that as a result of an acquisition creditors lose $\$ 20$, shareholders gain $\$ 10$ and no other 
creditors' protections come only from the covenants in their indenture and from the extra contractual protections found in discrete legal rules of the kind mentioned above. ${ }^{27}$

The foregoing discussion and example show that corporate managers' fiduciary duty to shareholders is defined in terms of the duty to maximize the total wealth of shareholders considered as a whole. There is, however, a second component to the fiduciary duty of corporate managers, and that is a duty to refrain from facilitating wealth transfers detrimental to any portion of the shareholders. ${ }^{28}$ Even if a transaction increases shareholder wealth considered as a whole, managers breach their fiduciary duty by facilitating a transaction that transfers wealth from any group of shareholders (minority shareholders, for instance) to other shareholders (majority shareholders, for instance) or to non-shareholder constituencies.

This rule can be illustrated by an example based roughly on Weinberger $v$. UOP, Inc. ${ }^{29}$ Assume that Parent owns a majority interest in Subsidiary and that the managers of Subsidiary, who are nominees of Parent, facilitate a merger of the Subsidiary into Parent in which minority shareholders of Subsidiary are frozen out at an unfairly low cash price. Assume further that the transaction is neutral regarding creditor wealth and generates

corporate constituency is affected. Even in that case, where the acquisition generates negative synergies, creditors would have no basis for a claim that the transaction violated any fiduciary duty owed to them.

27. The court in Katz, 508 A.2d at 879, stated,

[i]t is the obligation for directors to attempt, within the law, to maximize the long-run interests of the corporation's stockholders; that they may sometimes do so "at the expense" of others ... does not for that reason constitute a breach of duty. It seems likely that corporate restructurings designed to maximize shareholder values may in some instances have the effect of requiring bondholders to bear greater risk of loss and thus in effect transfer economic value from bondholders to stockholders. . . But if courts are to provide protection against such enhanced risk, they will require either legislative direction to do so or the negotiation of indenture provisions designed to afford such protection.

28. Two examples of transactions that may involve wealth transfers detrimental to some part of the shareholders are, first, affiliated acquisitions, which are discussed below in the text, and, second, single company recapitalizations, by which we mean corporate transactions that affect the rights of shareholderusually preferred shareholders-but that otherwise do not change the nature of the corporation or its assets. Examples of cases involving single company recapitalizations include: Goldman v. Postal Tel., Inc., 52 F. Supp. 763 (D. Del. 1943) (changing preferred's liquidation preference); Bowman v. Armour \& Co., 160 N.E.2d 753 (IIl. 1959) (changing redemptive rights); Bove v. The Cmty. Hotel Corp. of Newport, Rhode Island, 249 A.2d 89 (R.I. 1969) (changing preferreds' entire bundle of rights). The following are examples of cases in which preferred shareholders' dividend arrearages were eliminated: Barrett v. Denver Tramway Corp., 53 F. Supp. 198 (D. Del. 1943), aff'd, 146 F.2d 701 (3d Cir. 1944); Western Foundry Co. v. Wicker, 85 N.E.2d 722 (III. 1949); State ex rel. Weede v. Bechtel, 31 N.W.2d 853 (lowa 1948), cert. denied, 337 U.S. 918 (1949); Dratz v. Occidental Hotel Co., 39 N.W.2d 341 (Mich. 1949).

Although many of the single company recapitalization cases are older and thus do not benefit from more modern jurisprudence and scholarship regarding fiduciary duties, the cases generally hold that corporate managers or controlling shareholders must avoid transactions that treat the preferred shareholders in a manner that is unfair, grossly unfair, or amounts to constructive fraud. See, e.g., Bailey v. Tubize Rayon Corp., 56 F. Supp. 418 (D. Del. 1944) ("so unfair as to amount to constructive fraud . . . [and] "gross unfairness;" although actual analysis appears to utilize a more rigorous fairness standard); Barrett, 53 F. Supp. at 198, aff d, 146 F.2d 701 (3d Cir. 1944) ("constructive fraud," "bad faith," and "gross unfairness"); Bowman, 160 N.E.2d at 752 ("actual or constructive fraud" or "bad faith or reckless indifference"); Bove, 249 A.2d at 89 (concluding that recapitalization met the most rigorous faimess standard).

29. 457 A.2d 701 (Del. 1983). The facts of that case as reported suggest that the acquisition of UOP by Signal generated efficiencies that increased shareholder wealth as a whole. 
efficiencies that enhance total shareholder wealth. The problem, of course, is that the merger effects a wealth transfer from minority shareholders to majority shareholders, and that amounts to a breach of managers' fiduciary duties to minority shareholders, even though total value of shareholder wealth is increased by the freeze-out merger.

Corporate managers' fiduciary duties, therefore, are defined by reference both to wealth maximization and wealth transfers. Simply stated, managers owe a duty to maximize the total wealth of shareholders as a whole and owe a duty not to facilitate wealth transfers detrimental to any group of shareholders.

While the fiduciary duty of corporate managers is stated in terms of a duty to act in the best interests of shareholders, that duty has always been subject to certain carve-outs that permit corporate managers to make limited wealth transfers from shareholders to other corporate constituencies. Importantly, however, these carve-outs have never been defined as a duty to make such wealth transfers. Rather, the carve-outs only amount to a right to make such transfers, and the right has always been subject to explicit or implicit limitations.

One finds various examples of these carve-outs from the obligation to maximize shareholder wealth. Familiar examples of carve-outs include the rights of corporate managers to cause their corporation to make charitable contributions, ${ }^{30}$ deploy defensive tactics in the face of an unsolicited takeover bid, ${ }^{31}$ and make transfer payments to employees. ${ }^{32}$

Constituency statutes are legislatively approved examples of such carve-outs. ${ }^{33}$

30. MODEL BUS. CORP. ACT $\S 3.02$ (2005) (granting the general power to "do all things necessary or convenient . . . including . . . power: . . (13) to make donations for the public welfare or for charitable, scientific, or educational purposes"); see PRINCIPLES OF CORPORATE GOVERNANCE $\S 2.01(b)$ (1994) (authorizing gifts of a "reasonable amount of resources to public welfare . . . and philanthropic purposes," even though "corporate profit and shareholder gain are not thereby enhanced").

31. For example, Principles of Corporate Governance states that a board facing an unsolicited tender offer may deploy defensive measures "if the action is a reasonable response to the offer." PRINCIPLES OF CORPORATE Governance $\S 6.02$ (a) (1994). Principles goes on to state that in determining whether the action is "reasonable" the board may "have regard for interests or groups (other than shareholders) ... if to do so would not significantly disfavor the long-term interests of shareholders." Id. $\S 6.02(\mathrm{~b})(2)$. One finds similar language from significant acquisition cases. See, e.g., Unocal Corp. v. Mesa Petroleum Co., 493 A.2d 946, 955 (Del. 1985) (finding a right in the face of an unsolicited takeover bid for board to consider "impact on 'constituencies' other than shareholders (i.e., creditors, customers, employees, and perhaps even the community generally)").

32. See, e.g., Principles of Corporate Governance $\$ 2.01$ (b) illus.20 (1994) (Here, an example is given involving a legally non-required payment to employees that are discharged by the company due to the company's closing of a plant. Even though such payments were not wealth maximizing for shareholders or the corporation, payments were a permissible "humanitarian" undertaking for the company.).

33. Presently, about thirty states have some form of a constituency statute. See Martin Lipton, Twenty-Five Years after Takeover Bids in the Target's Boardroom: Old Battles, New Attacks and the Continuing War, 60 BUS. LAW. 1369, 1371 n.3 (2005) ("Approximately thirty states currently have constituency statutes in effect." $\mathrm{Mr}$. Lipton provides citations to all such states.).

The following are examples of some of the thoughtful articles that have been written on constituency statutes: James J. Hanks, Jr., Playing with Fire: Nonshareholder Constituency Statutes in the 1990s, 21 STETSON L. REV. 97 (1991); James J. Hanks, Jr., Evaluating Recent State Legislation on Director and Officer Liability Limitation and Indemnification, 43 BUS. LAW. 1207 (1988); Alexander C. Gavis, A Framework for Satisfying Corporate Directors' Responsibilities Under State Nonshareholder Constituency Statutes: The Use of Explicit Contracts, 138 U. PA. L. REV. 1451 (1990). 
Broader versions of constituency statutes apply to any actions of directors ${ }^{34}$ and typically expressly permit directors in taking action on behalf of the corporation to consider, in addition to the interests of the company's shareholders, the "interests of . . . employees, suppliers, creditors [and others] . ..."35 The statutes amount to express permission for directors to facilitate actions that transfer wealth from shareholder to non-shareholder constituencies. In all cases, however, there are significant limits on the amount of shareholder wealth that managers may transfer to non-shareholder constituencies. The limits are usually described in general terms of "reasonableness."

Principles of Corporate Governance, ${ }^{36}$ along with its comments and illustrations, illuminate this "reasonableness" limitation. For example, Principles affirms the right of management to make a "reasonable amount" of charitable contributions. ${ }^{37}$ Regarding the use of defensive tactics in the face of an unwanted takeover bid, Principles affirms the right of the board to take such action, so long as it "would not significantly disfavor the long-term interests of shareholders." 38 Perhaps the best illumination from Principles of the "reasonableness" limitation is in two illustrations in which a company proposes to continue operating an unprofitable plant in order to benefit non-shareholder constituencies, principally employees. ${ }^{39}$ The illustrations conclude that the board could continue to operate the plant for a short period of time to ease the plight of employees who will lose their jobs but that the company is quite limited in how long it may operate the plant and how much of a loss is "reasonable" in such circumstances.

The positive analysis we offer in this Part leads to the conclusion that corporate managers' fiduciary duties in normal or solvent periods are defined by reference to the best interest of the company's shareholders. Corporate managers owe a fiduciary duty to maximize total shareholder wealth and a duty not to facilitate wealth transfers detrimental to any of the shareholders. These duties, however, are subject to certain carve-outs that enable managers to facilitate limited amounts of wealth transfers from shareholders to other corporate constituencies. Corporate managers owe no similar fiduciary duties to

34. See, e.g., KY. REV, STAT. ANN. \$ 271B.12-210(4) (2005) (providing that directors may consider nonshareholder constituencies in discharging duties in connection with business combinations "or otherwise").

35. See, e.g., id. Under that statute, directors

may consider in addition to the interests of the corporation's shareholders, any of the following:

(a) The interests of the corporation's employees, suppliers, creditors and customers;

(b) The economy of the state and nation;

(c) Community and societal considerations; and

(d) The long-term as well as short-term interests of the corporation and its shareholders, including the possibility that these interests may be best served by the continued independence of the corporation.

36. PRINCIPLES OF CORPORATE GOVERNANCE (1994).

37. Id. $\S 2.01$ (b) (1994) (emphasis added) (authorizing gifts of a "reasonable amount of resources to public welfare ... and philanthropic purposes," even though "corporate profit and shareholder gain are not thereby enhanced").

38. Id. $\S 6.02(\mathrm{~b})(2)$ (emphasis added) (The board may deploy defensive tactics in the face of an unsolicited bid "if the action is a reasonable response to the offer," $i d . \$ 6.02(\mathrm{a})$, and in determining whether defensive tactics are "reasonable," the board may "have regard for interests or groups (other than shareholders) ... if to do so would not significantly disfavor the long-term interests of shareholders," id. § 6.02(b)(2).).

39. Id. $\S 2.01$ illus. $19 \& 20$. 
creditors. As a result, except for a very few discrete rules, such as limitations on the payment of dividends and prohibitions against fraudulent transfers, creditors for their own protection must rely on contractual protections that they construct and negotiate in each deal.

\section{B. In Periods of Insolvency and Its Vicinity}

While the positive analysis we offer in the preceding Part suggests that corporate managers' fiduciary obligations in normal or solvent periods is to pursue the best interests of shareholders, courts in some cases-principally in cases from Delawarehave constructed different fiduciary duty regimes that they apply when the company is in or approaching insolvency. These cases raise difficult interpretative matters that include not only the matter of defining the nature of fiduciary duties during these periods but also the matter of defining the perimeters of the periods themselves.

\section{Insolvency}

Under Delaware law, once a company becomes insolvent, the duty of the corporation's managers no longer amounts to an obligation to pursue the best interests of shareholders. Instead, as the Delaware court stated in Geyer v. Ingersoll Publications $\mathrm{Co},{ }^{40}$ directors of an insolvent firm operating outside bankruptcy owe fiduciary duties to company's creditors. ${ }^{41}$ Delaware defines insolvency in this context as either "a deficiency of assets below liabilities with no reasonable prospect that the business can be successfully continued in the face thereof," or "an inability to meet recurring obligations as they fall due in the usual course of business." 42

The reason offered for this dramatic shift-away from the normal obligation of managers to maximize shareholder wealth-is that during insolvency creditors, as opposed to shareholders, bear the brunt of damages for stupid or dishonest managerial conduct. ${ }^{43}$ If, to use a simple example, the value of a company's assets is 80 and the claims of creditors are 100 , a bad managerial decision that reduces the value of the firm to 60 injuries, most apparently, the creditors, not the shareholders, who were underwater even before the bad act. Not only does this shift rest on problematic policy bases-a

40. Geyer v. Ingersoll Publ'ns Co., 621 A.2d 784 (Del. Ch. 1992).

41. Id. at 787, cited with approval in Prod. Res. Group, LLC v. NCT Group, Inc., 863 A.2d 772, 790-91 n.58 (Del. Ch. 2004).

42. Siple v. S \& K Plumbing and Heating, Inc., No. 6731, 1982 WL 8789, at *28 (Del. Ch. Apr. 13, 1982) (citing Kenny v. Allerton Corp., 151 A. 257 (Del. Ch. 1930); Freeman v. Hare \& Chase, Inc., 142 A. 793 (Del. Ch. 1928)), cited with approval in Prod. Res. Group, LLC, $863 \mathrm{~A} .2 \mathrm{~d}$ at $782 \mathrm{n} .28$. In In re Healthco Int'l, Inc., 208 B.R. 288, 300 (D. Mass. 1997), the court appears to extend this fiduciary duty owed by managers to creditors into the period before the company becomes insolvent. The court stated: "When a transaction renders a corporation insolvent, or brings it to the brink of insolvency, the rights of creditors become paramount." Id. (emphasis added). This appears to contradict the position of the Delaware Court of Chancery in Credit Lyonnais. See infra notes 55-58 and accompanying text (defining managers' fiduciary duties in the "vicinity of insolvency" as being owed to the "community of interest").

43. See Prod. Res. Group, $L L C, 863$ A.2d at 790-93 (describing creditors of an insolvent corporation as "the principal constituency injured" by mismanagement). In Hechinger Inv. Co. of Del. v. Fleet Retail Fin. Group, 274 B.R. 71, 89 (D. Del. 2002), the court stated that when a company "enters the zone of insolvency, the creditors-and not just the shareholders-are residual risk bearers;" the court stated that "directors can be said to be "playing with creditors money." 
matter we discuss later ${ }^{44}$ _ but also this shift in insolvent periods toward protecting the interests of creditors generates a number of difficult interpretative issues.

We are, for example, able to offer at least three alternative interpretations regarding the nature of any such fiduciary duties owed to creditors. The first possible interpretation is that the creditors and shareholders simply exchange places as the beneficiaries of corporate managers' fiduciary duties. Under this approach, at least as we have defined corporate managers' duties during normal periods, managers during insolvency would be obliged to maximize the value of the creditors' claims, subject to the right, but not any obligation, to make reasonable amounts of wealth transfers from creditors to other constituencies, including shareholders. This represents a strong version of fiduciary duties to creditors.

Under a semi-strong version of a fiduciary duty to creditors, managers during insolvency would be obliged to consider the best interests of creditors and shareholders as a whole. ${ }^{45}$ This version is analogous to managers' present fiduciary duties during normal periods to minority and majority shareholders as a whole. Managers operating in normal or solvent periods presently have fiduciary duties both to the minority and majority shareholders-even though the interests of these two groups of shareholders may differ-and are obligated to maximize the total value of the shareholder interests as a whole and are prohibited from facilitating wealth transfers between groups of shareholders. ${ }^{46}$

A third possible interpretation is a weak version of fiduciary duties to creditors. Under this interpretation, managers would continue to owe their primary duties to shareholders but would be accorded more leeway in making decisions that effect wealth transfers from shareholders to creditors. To use an example, if one assumes that in a normal or solvent corporation a board, consistent with the members' fiduciary duties, perhaps could make a decision that reallocated $5 \%$ of shareholder wealth to creditors, in an insolvent period the board perhaps could reallocate $30 \%$ of shareholder wealth to creditors. ${ }^{47}$

The confusion regarding the nature of corporate managers' duties when operating in a period of insolvency is significant and pernicious. ${ }^{48}$ Perhaps most obviously,

44. See infra notes 127-134 and accompanying text

45. This would be similar to the rule that we believe applies during Chapter 11 reorganizations, when managers are obliged to maximize the value of the bankruptcy estate. See infra notes 80-94 and accompanying text.

46. Weinberger v. UOP, Inc., 457 A.2d 701 (Del. Ch. 1983), is based on the rule that managers operating in solvent periods breach their fiduciary duty by facilitating a transaction that transfers wealth from minority shareholders to majority shareholders. See generally Campbell, supra note 1, at 455-69 (describing, with graphic representations, fiduciary duties to shareholders and the fiduciary duty rule that prohibits corporate managers from facilitating wealth transfer transactions detrimental to any shareholder group).

47. This appears to be the interpretation of Chancellor Strine in Prod. Res. Group, LLC, 863 A.2d 772 at 789 (quoting Weaver v. Kellogg, 216 B.R. 563, 582-84 (Bankr. S.D. Tex. 1997)) with regard to fiduciary duties of corporate managers when the corporation is in the "vicinity of insolvency." See infra notes 68-71 and accompanying text.

48. Unfortunately, court decisions following Geyer have only confused matters more. One of the most dramatic examples of a court's confusion can be seen in Hechinger Inv. Co. of Del., 274 B.R. at 71. In considering whether directors of Hechinger acted consistent with their fiduciary duties when they approved a leveraged buyout (LBO), the court assumed in a motion to dismiss that Hechinger was insolvent at the time of the approval of the LBO. The court at one point states that "insolvency triggers fiduciary duties for directors for 
uncertainty over the proper interpretation of the duty to creditors makes it difficult for managers operating in periods of insolvency to make legally proper decisions. Assume, for example, that corporate managers operating in insolvency are offered two alternate investment opportunities for the company. Confusion about which interpretation of the duty to creditors is applicable may make it impossible for managers to select the investment that is consistent with their legal duties to creditors. ${ }^{49}$

While, certainly, we are concerned with the plight of corporate managers attempting to deal with the meaning of their duty to creditors in times of insolvency, also important to us are the problems the confusion generates regarding investment risk allocation and pricing of capital by investors. When investors contribute their capital to a corporate enterprise, they demand a return that depends on the terms of their investment contract. Implicit in shareholders' investment contract is an obligation that corporate managers will act to maximize the value of their interests, and shareholders price their investment in light of that managerial obligation. A corollary is that corporate creditors construct the terms of their investment contract and price their investment based on the assumption that no fiduciary duties are owed to them. Confusion on the part of shareholders and creditors regarding these duties of corporate managers may lead to unintended outcomes, which means that investors may have mispriced their capital. ${ }^{50}$ Efficient and accurate ex ante

the benefit of creditors . . . "Id. at 89 (emphasis added). In the immediately following paragraph, however, the court states that "in insolvency, the directors' . . f fiduciary duties are to multiple constituencies . . . [and] that in insolvency the duty runs not directly to the creditors but to the "community of interest." Id. (emphasis added). This reflects a fundamental confusion regarding the beneficiaries of managers' fiduciary duties when the company is insolvent. When operating in insolvency, do corporate managers owe a duty to act in the best interests of creditors, or do they owe a duty to act in the best interests of some combination of the corporation's constituencies (e.g., some combination of creditors, preferred shareholders, majority common shareholders, minority common shareholders, employees, suppliers, the community, etc.)?

49. Consider the following example in that regard. Assume $B$ Co. is insolvent with assets worth 80 and creditors' claims amounting to 100 . Managers are offered two alternate re-investment opportunities. The first is an opportunity to re-invest the company's assets in a project with a $50 \%$ chance of amounting to 100 and a $50 \%$ chance of amounting to 80 . The project has a total expected value of $90(0.5(80)+0.5(100)=90)$, and creditors reap the entire gain. Shareholders still have an expected value of 0 . The second opportunity involves a project with a $50 \%$ chance of amounting to 50 and a $50 \%$ chance of amounting to 150 . The expected value of that project is $100(0.5(50)+0.5(150)=100)$, which as a whole is superior to the first project. Creditors, however, are worse off, since the expected value of their claim is $75(0.5(50)+0.5(100)=75)$. Shareholders are better off under this investment, since their claim now has an expected value of $25(0.5(0)+0.5(50)=25)$. For similar examples, see Alon Chaver \& Jesse M. Fried, Managers' Fiduciary Duty Upon the Firm's Insolvency: Accounting for Performance Creditors, 55 VAND. L. REV. 1813, 1821 -25 (2002); Laura Lin, Shift of Fiduciary Duty Upon Corporate Insolvency: Proper Scope of Directors' Duty to Creditors, 46 VAND. L. REV. 1485, 148991 (1993).

Under the strong version of fiduciary duties to creditors-obligating managers to act in the best interests of creditors-managers would likely be obliged to select the first investment, since it maximizes the creditors' interests. Under the semi-strong version-obligating managers to maximize the value of the interests of creditors and shareholders as a whole-managers would likely be obliged to select the second investment but may still face the question of whether a fiduciary duty to creditors can be reconciled with a transaction that actually decreases the wealth of creditors. Under the weak version of the duty to creditors-obligating managers to act in the best interests of shareholders but permitting them to make larger wealth transfers to creditorsmanagers may be able to choose either investment and still be consistent with their fiduciary duties.

50. Assume, for example, that an investor taking an equity position in a corporation requires a $10 \%$ return on her investment, due in part because the investor believes that managers in all instances are obliged to pursue a path that maximizes the value of shareholders' interests. If, instead, the rule is that at some point managers' 
allocation of risk of loss and pricing depend on intelligible rules regarding the beneficiaries of corporate managers' fiduciary duties.

Notwithstanding the substantial confusion in this area, our positive analysis supports the conclusion that the duty of managers during periods of insolvency run to creditors and that courts are most likely to interpret this duty in terms of creditors' stepping into the shoes of shareholders. Our positive conclusions are supported by Chancellor Strine's analysis in Production Resources. ${ }^{51}$ After describing directors in insolvency as owing "fiduciary duties to the company's creditors," 52 Strine suggests strongly that the only change in directors' duties in insolvency is a change in "the constituency on whose behalf the directors are" to pursue wealth maximization. ${ }^{53}$ In a footnote in a subsequent case, Trenwick America Litigation Trusts v. Ernst \& Young, L.L.P., Chancellor Strine once again appears to take a similar position. ${ }^{54}$

\section{Vicinity of Insolvency}

Delaware courts have created a third zone that might be described as a prebankruptcy period in which the company is near, yet short of, actual insolvency. ${ }^{55}$ The seminal case here is Credit Lyonnais, ${ }^{56}$ where Chancellor Allan stated that when "a

duties shift to an obligation to pursue a path that maximizes the best interests of creditors, the equity investor may demand a return of $11 \%$ (rather than $10 \%$ ) on her investment. Similarly, a creditor who demands a $6 \%$ interest rate, due in part because the investor believes that managers are in all instances obliged to pursue a path that maximizes the value of shareholders' interests, may be willing to accept a $5 \%$ interest rate, if managers are required at some point to act in creditors' best interests. Confusion about the existence of a rule requiring this shift or the meaning of the obligation to act in the best interests of creditors may make it impossible for shareholders and creditors to price their investments.

51. Prod. Res. Group, LLC v. NCT Group, Inc., 863 A.2d 772 (Del. Ch. 2004).

52. Id. at 791 .

53. Id.

54. Trenwick Am. Litig. Trusts v. Ernst \& Young, L.L.P., 906 A.2d 168, 195 n.75 (Del. Ch. 2006). Although this interpretation has a symmetrical appeal and may seem easiest to apply, courts applying a stepinto-the-shoes duty on behalf of creditors will still have tough issues to consider. One such issue is the extent to which, under a step-into-the-shoes regime, managers are permitted to take an action that benefits the unprivileged constituency- which now includes shareholders-at the expense of the privileged class-which is now the creditors. In Trenwick, Strine indicates that in his view directors operating in periods of solvency or periods of insolvency have the same latitude to act in ways that benefit the unprivileged at the expense of the privileged. Id.

In normal or solvent periods, we concluded that transactions benefiting creditors (an unprivileged constituency) at the expense of shareholders (the privileged constituency) may be possible, provided such wealth transfers were reasonable in amount. See supra notes 30-39 and accompanying textual discussion. Some commentators, however, argue that directors have nearly unlimited power in solvent periods to transfer wealth from shareholders to creditors and other corporate constituencies. See supra note 19 and accompanying text. Importing into the insolvent period this more aggressive interpretation of managers' rights to facilitate wealth transfers away from the beneficiaries of their fiduciary duties-in a reversed form, of course--would seem to do substantial damage to the interests of creditors. In short, the more aggressive interpretation imported into insolvency would permit (but not require) managers to continue to act in the best interests of shareholders throughout the period of insolvency.

55. One of the problems with this third zone is the difficulty in defining its perimeter. See infra note 61 and accompanying text. Our description of the perimeter-"near, yet short of, actual insolvency"-is not intended as a basis for any definition or re-definition of the vicinity of insolvency.

56. Credit Lyonnais Bank Nederland N.V. v. Pathe Commc'ns Corp., Civ. A No. 12150, 1991 WL 277613 (Del. Ch. Dec. 30, 1991). 
corporation is operating in the vicinity of insolvency, a board of directors is not merely the agent of the residue risk bearers, but owes its duty to the corporate enterprise." 57 Chancellor Allan continued, stating that the board's obligation in such circumstances is "to the community of interest that sustained the corporation . . . to maximize the corporation's long-term wealth creating capacity." 58

Reserving for later a consideration of the appropriateness of repeatedly shifting fiduciary standards as a company passes from solvency to the vicinity of insolvency to actual insolvency, ${ }^{59}$ the opinion in Credit Lyonnais creates a number of difficult interpretative problems. 60

Commentators have pointed out, for example, the obvious interpretative difficulty in charting the perimeter of the "vicinity of insolvency." 61 It is an inherently vague standard, which the Court in Credit Lyonnais made no attempt to define. ${ }^{62}$ With managers now facing three different fiduciary obligations-depending on whether the company is solvent, insolvent or in the vicinity of insolvency-managers are left with little idea about when they might be in the vicinity of insolvency and thus legally bound to pursue a path that is consistent with their obligation to the "community of interest," instead of a path that is consistent with either the best interests of shareholders (solvent period) or the best interests of creditors (insolvent period).

Equally perplexing and troublesome are ambiguities concerning the scope of the "corporate enterprise" or the "community of interest," 63 which the Credit Lyonnais case makes the beneficiary of managers' fiduciary duties while the corporation is operating in the vicinity of insolvency. ${ }^{64}$ The discussion of the court in Credit Lyonnais focuses entirely on two constituencies-shareholders and creditors. ${ }^{65}$ There are, however, other

57. Id. at $* 34$.

58. Id.

59. See infra notes 123-136 and accompanying text.

60. The opinion in In re Healthco Int'l, Inc., 208 B.R. 288 (Bankr. D. Mass. 1997), shows the confusion in this area. Healthco appears to make creditors the beneficiaries of managers' fiduciary duties in the vicinity of insolvency, although this certainly is not entirely clear from the opinion. In Healthco the court stated: "When a transaction renders a corporation insolvent, or brings it to the brink of insolvency, the rights of creditors become paramount." Id. at 300 (emphasis added). This appears contrary to the position of the Delaware court in Credit Lyonnais, which defines managers' fiduciary duties in the "vicinity of insolvency" as being owed to the "community of interests." Credit Lyonnais, 1991 WL 277613, at *34 n.55. See supra notes 56-58 and accompanying text. It is also unclear, whether the "brink of insolvency" in Healthco is the same as the "vicinity of insolvency" in Credit Lyonnais. See infra note 62 and accompanying textual discussion.

61. See, e.g., Royce de R. Barondes, Fiduciary Duties of Officers and Directors of Distressed Corporations, 7 GEO. MASON L. REV. 45, 72 (1998) ("If uncertainty necessarily exists as to whether a corporation's financial position meets a well-articulated test-one of the multiple definitions of insolvencythis uncertainty is compounded as to whether a corporation's financial position meets an imprecise test.").

62. Id. at 72 ("The Court did not even announce an imprecise test as to when a corporation is in the vicinity of insolvency.").

In Healthco, the court uses the term "brink" of insolvency and attempts to amplify the meaning of this term as a situation in which the corporation has "unreasonably small capital," or when the corporation faces an "unreasonable risk of insolvency, not necessarily a likelihood of insolvency." In re Healthco Int'l, Inc., 208 B.R. at 302; see supra note 42 and accompanying discussion.

63. Professor Barondes is also troubled by the ambiguity in the term "wealth creating capacity." See, e.g., Barondes, supra note 61 , at 74.

64. Credit Lyonnais, 1991 WL 277613 , at *34.

65. Id. \& n.55. 
corporate constituencies that might be included in the "community of interest," including, for example, employees and the community. ${ }^{66}$ What is uncertain is whether the obligation of managers operating in the vicinity of insolvency to maximize the best interests of the "community of interest" requires or permits managers to consider the best interests of constituencies such as employees and the community, or, alternatively, whether managers are only to consider the interests of shareholders and creditors. ${ }^{67}$

Chancellor Strine's sweeping dictum in Production Resources ${ }^{68}$ exacerbates the ambiguities of Credit Lyonnais. To Strine, Credit Lyonnais dictates no fundamental shift in corporate managers' fiduciary obligations when their company enters the vicinity (or, as he calls it, the "zone") of insolvency. ${ }^{69}$ The fundamental obligation to act in the best interests of shareholders continues. Strine views Credit Lyonnais as merely creating a "shield" for corporate managers, a shield that apparently allows managers operating in the vicinity of insolvency more discretion to make decisions that benefit creditors at the expense of shareholders. ${ }^{70}$ In short, the duty of corporate managers in the vicinity of insolvency, as Strine sees it, continues to be an obligation to act in the best interests of shareholders, subject, however, to an expanded right (but not obligation) to transfer wealth from shareholders to creditors.

Strine's fundamental point-that moving from solvency to the vicinity or zone of insolvency should not change managers' basic fiduciary obligation to act in the best interests of shareholders-is in our view sound. ${ }^{71}$ The interpretative difficulty, however, is that Strine's rule in Production Resources cannot be reconciled with Credit Lyonnais. Simply stated, the rule from Production Resources is that managers operating in the vicinity of insolvency owe the duty to maximize the interests of shareholders, subject to an expanded right to take actions that benefit non-shareholder constituencies at the expense of shareholders. The rule from Credit Lyonnais is that managers in the vicinity of insolvency owe the obligation to maximize the interests of corporate constituencies as a whole. Those amount to different rules that posit different duties for managers and thus

66. See, e.g., Unocal Corp. v. Mesa Petroleum Co., 493 A.2d 946, 955 (Del. 1985) (target board may in the face of an unsolicited takeover bid consider "impact on 'constituencies' other than shareholders (i.e., creditors, customers, employees, and perhaps even the community generally)"). See generally the discussion of constituency statutes at notes 33-35 and accompanying text, supra.

67. Consider the following example, which is based to some extent on an illustration from the Principles of Corporate Governance. See PRINCIPLES OF CORPORATE GOVERNANCE $§ 2.01$, at 67 illus. 19 \& 20 (1992). While operating in the vicinity of insolvency, managers are faced with a decision whether to close an unprofitable plant, which will result in the lay off of 1,000 employees and economic devastation of the small community in which the plant is located. Closing the plant will increase the value of the interests of shareholders and creditors as a whole but will be contrary to the best interests of employees who will lose their jobs and the community which will lose its major employer. It may be that, considered as a whole, the interests of shareholders, creditors, employees and the community will actually decrease in total, but, obviously that is nearly impossible to determine.

68. Prod. Res. Group, LLC v. NCT Group, Inc., 863 A.2d 772 (Del. Ch. 2004).

69. See, e.g., id. at $788 \mathrm{n} .52$ (stating that it "seems ... less plausible that directors' duties somehow change profoundly as the firm approaches insolvency").

70. Strine states that "Credit Lyonnais provided a shield to directors from stockholders who claimed that the directors had a duty to undertake extreme risk . ..."Id. at 788. The imagined facts are that the company is offered an investment opportunity that will reduce the value of the interests of the creditors and shareholders considered as whole but will benefit shareholders.

71. See infra notes $127-136$ and accompanying text. 
may obligate managers to pursue different paths in order to comply with their fiduciary duties.

Our positive analysis suggests to us that courts are likely to take Credit Lyonnais at face value and thus are likely to apply the rule as there articulated-that when operating in the vicinity of insolvency, managers owe fiduciary duties to "the community of interest." We fully appreciate, however, the confusion on this matter and that Chancellor Strine's opinion in Production Resources only adds to the confusion regarding the proper interpretation of Credit Lyonnais. We also reiterate the point from the immediately preceding section of this paper-that the confusion has pernicious effects on corporate managers attempting to comply with their fiduciary duties and on the efficient allocation and pricing of investment risks. ${ }^{72}$

\section{Bankruptcy Court's Interpretations of Managers' Duties Before Bankruptcy: Weiboldt Stores, Inc. v. Schottenstein}

Under the positive analysis that we have so far constructed, the nature of managers' fiduciary duties depends on the financial situation of their company at the time managers take the action in question. Thus, if at the time managers' actions occur the corporation is solvent, managers' fiduciary duties are to shareholders; if, however, at the time of the managers' action the corporation is in the vicinity of insolvency, managers' duties are to the community of interest, and if the corporation is insolvent at the time, managers owe their duties to creditors.

The court in Wieboldt Stores, Inc. v. Schottenstein, ${ }^{73}$ however, appears to apply a different analysis. Weiboldt suggests-perhaps rather strongly - that any claim of a prebankruptcy breach of fiduciary duty against corporate managers, if raised in a bankruptcy proceeding, will be measured against the best interests of creditors, no matter whether at the time of the alleged breach the company was solvent, in the vicinity of insolvency or insolvent.

In Weiboldt, corporate managers approved a series of transactions in an LBO that resulted in lucrative payments to shareholders and that added substantial secured debt owed by Weiboldt. In less than a year, the company filed a bankruptcy petition, and the debtor in possession representing the interests of the unsecured creditors sued the managers, claiming, inter alia, ${ }^{74}$ that managers breached their fiduciary duties by facilitating the LBO and thereby failing to preserve the corporate assets for the benefit of creditors.

The court in Weiboldt found that the complaint alleged sufficient facts to support a

72. See supra note 50 and accompanying text.

73. 94 B.R. 488 (Bankr. N.D. Ill. 1988).

74. The plaintiff also claimed that the LBO involved actual or constructive fraudulent transfers and was thus voidable under $\S 548$ of the Bankruptcy Code, 11 U.S.C $\S 548$ (2006). Weiboldt, 94 B.R. at 493 (plaintiff sought "to avoid the transactions constituting the LBO on the grounds that they are fraudulent under federal and state fraudulent conveyance laws"). Such claims have become common in bankruptcies resulting from failed LBOs and are based on the idea that because the proceeds of the acquisition debt are paid to the shareholders, the target corporation receives less than a reasonably equivalent value for the debt. A successful application of the theory results in some combination of a recovery of the amounts paid to shareholders and a cancellation of the debt and security interests incurred and granted in the deal. 
breach of fiduciary duty claim against the directors. ${ }^{75}$ While the analysis and the language of the court are confusing, the decision rests squarely on a duty that managers owed to creditors, ${ }^{76}$ and the opinion offers no suggestion that the obligation to creditors depends on the corporation's insolvency. So interpreted, the case would recognize a fiduciary duty to creditors anytime a claim for a pre-bankruptcy breach of that duty is raised in a bankruptcy proceeding, irrespective of whether at the time of managers' actions the company was solvent, in the vicinity of insolvency or insolvent.

This interpretation of Weiboldt creates havoc for managers. Consider, once again, the circumstances of corporate managers in a solvent period who are offered an opportunity for a LBO that benefits shareholders at the expense of creditors. Managers facilitating such a transaction would be found to be acting consistent with their fiduciary duties if a claim were brought against them outside a bankruptcy proceeding, but inconsistent with their fiduciary duties if the claims were brought as part of a bankruptcy proceeding.

Despite its confusing analysis and sweeping rhetoric, we consider Weiboldt an early application of the general principle described above, which is that creditors become the beneficiaries of managers' fiduciary obligations when the company is insolvent. This interpretation of Weiboldt is factually supportable, since the court in its analysis of the fraudulent transfer claims noted that Weiboldt was allegedly insolvent at the time of the transaction, and that the LBO resulted in further insolvency. ${ }^{77}$ Moreover, fiduciary duty claims such as these are not a creation of bankruptcy law, but are simply state law claims that are owned by the debtor and, upon filing, become property of the bankruptcy estate. ${ }^{78}$ Thus, rather than announce a principle of bankruptcy law, Weiboldt is best understood as a case about state fiduciary duty law that is applicable in periods of insolvency. Subsequent bankruptcy cases may support this more limited reading of Weiboldt. ${ }^{79}$

75. Weiboldt, 94 B.R. at 510 .

76. For example, the court at one point stated that "[a] corporate board of directors has a fundamental duty to protect the corporate enterprise from 'harm reasonably perceived, irrespective of its source." Id. at 509 (citing Unocal Corp. v. Mesa Petroleum, 493 A.2d 946, 954 (Del. 1985)). At another point the court stated that the board is required to "determine whether the offer is in the best interests of the corporation and its shareholders." Id. at 509-10. At another point the language appears to recognize that the core beneficiaries of managers' fiduciary duties are creditors: "Weiboldt, as debtor-in-possession of its bankrupt estate, clearly may assert a claim for breach of fiduciary duty on behalf of its group of unsecured creditors." Id. at 508-09.

Notwithstanding this confusing language, it is clear that creditors are the beneficiaries of the duties articulated in Weiboldt. The core of the claim in Weiboldt is that shareholders benefited by transferring wealth to themselves from creditors.

77. Id. at $\mathbf{5 0 2}$.

78. 11 U.S.C. $\$ 541$ (2006); Butner v. United States, 440 U.S. 48 (1979) ("Property interests are created and defined by state law. Unless some federal interest requires a different result, there is no reason why such interests should be analyzed differently simply because an interested party is involved in a bankruptcy proceeding."); see also In re Healthco Int'l, Inc., 208 B.R. 288, 300 (Bankr. D. Mass. 1997) ("Any Healthco claim is an interest in property which passed to the bankruptcy estate. The Trustee can bring any suit Healthco could have brought, including suits against directors and controlling shareholders for breach of fiduciary duty.").

79. In Hechinger Inv. Co. of Del. v. Fleet Retail Fin. Group, 274 B.R. 71 (Bankr. D. Del. 2002), fiduciary claims against corporate managers were bought by the Official Committee of Unsecured Creditors of Hechinger and arose, the Committee claimed, out of a LBO that: 
In all events, however, Weiboldt demonstrates once again the confusion wrought by courts in this area. The opinion obscures the true nature of the problem, which is a classic conflict between the interests of shareholders and creditors. The court, however, confusingly characterizes the duty of managers as running to the "corporation," while in fact holding that the duty runs to creditors. Additionally, all this is done with no explanation as to why the traditional duty to shareholders is not applicable.

\section{Duties of Corporate Managers in Bankruptcy Cases}

Chapter 11 of the Bankruptcy Code is designed to offer a collective response to the unique problems financially distressed firms face. As a firm's financial status worsens, individual creditors' natural incentive is to withdraw their capital--leading to a race to the courthouse that would, if unchecked, lead to an inefficient liquidation of the corporate assets. ${ }^{80}$ Chapter 11 stays individual debt collection actions, ${ }^{81}$ permits the continued

["S]hifted all of the risk of the Debtors' operations to their unsecured creditors" by cashing out [the shareholders'] equity interests in Hechinger while incurring on behalf of Hechinger hundreds of millions of unserviceable secured debt, at a time when the company was insolvent.

Id. at 75 (quoting amended complaint) (emphasis added).

In its discussion of the Committee's fiduciary duty claim, the court clearly tied its conclusion, that the defendants owed a duty to the creditors, to the Committee's allegation that Hechinger was insolvent at the time of the LBO. Id. at 90 . In fact, the court noted that if the fact of insolvency was taken as true, "defendants, as directors and controlling shareholders, cannot, and do not, contend that they do not owe certain fiduciary duties to the unsecured creditors." Id.

In re Healthco, 208 B.R. at 288 , also involved a LBO that resulted in a bankruptcy just over two years after the closing. Upon Healthco's bankruptcy filing, the trustee brought fraudulent transfer and breach of fiduciary duty claims against the directors. The defendant-directors challenged the Trustee's fiduciary duty claim, stating that their obligations were limited to protecting the shareholders' interests. The court stated, however, that where a transaction leaves a corporation insolvent or brings it to the brink of insolvency, "the rights of the creditors become paramount." In re Healthco, 208 B.R. at 300. In addition, the court stated that "directors of an insolvent Delaware corporation breach their fiduciary duties to creditors, even in the absence of formal insolvency proceedings, when they authorize fraudulent conveyances, which cause the corporation to be insolvent in fact." Id. at 301 (citing Geyer v. Ingersoll Publ'n Co., 621 A.2d 784 (Del. Ch. 1992))

Requiring directors to look out for the interests of creditors as well as stockholders involves no irreconcilable conflict, as contended by defendants. It is merely an incident of the fiduciary obligations owed by directors to their corporation. A distribution to stockholders which renders the corporation insolvent, or leaves it with unreasonably small capital, threatens the very existence of the corporation. This is prejudicial to all its constituencies, including creditors, employees, and stockholders retaining an ownership interest. Surely it is not asking too much of directors that they honor their obligations of loyalty and care to avoid the corporation's destruction.

Id.

80. The seminal article on bankruptcy as a response to collective action problems is Thomas $\mathrm{H}$. Jackson, Bankruptcy, Non-Bankruptcy Entitlements, and the Creditors' Bargain, 91 YALE L.J. 857, 907 (1982). See also Douglas G. Baird, Loss Distribution, Forum Shopping, and Bankruptcy: A Reply to Warren, 54 U. CHI. L. REV. 815,827 (1987).

81. The automatic stay, provided in 11 U.S.C. $\$ 362$, prohibits actions to collect debt, enforce judgments, and exercise control over property of the estate. This provision forces the parties to operate within the confines of the case. The automatic stay ensures that the pre-bankruptcy owners will participate in the proceeding by stopping all creditor collection efforts and interference with property of the state. Because financial problems do not occur overnight, the preference provisions of the Code provide a reach back to bring debts paid on the eve of bankruptcy within the proceeding. These provisions make bankruptcy a truly collective proceeding in which 
operation of the business and imposes a structure for collective negotiations over the future of the firm. ${ }^{82}$

The initiation of a Chapter 11 bankruptcy case thus marks a substantial change in the way the corporation is governed and, accordingly, a change in the fiduciary duties of corporate managers. ${ }^{83}$ Creditor contracts are no longer effective to control inefficient investment in risky projects desired by shareholders. In place of those contracts, Chapter 11 substitutes a governance regime that includes creditor representation, negotiation and default rules regarding the allocation of value in a reorganization plan, and judicial oversight over most important decisions. ${ }^{84}$

Under this regime, the law requires managers to fulfill the fiduciary responsibilities of a trustee to act in the interests of both creditors and shareholders. ${ }^{85}$ The point of convergence for these naturally opposed constituencies is the value of the assets, or, in bankruptcy parlance, the "estate." 86 Thus, bankruptcy courts often articulate the duty as one to maximize the value of the estate, rather than to benefit a particular group of claimants. ${ }^{87}$

Like non-bankruptcy courts' references to the "corporate enterprise" and "community of interests," 88 bankruptcy courts' reference to the estate may promote confusion regarding the beneficiaries of managerial duties in bankruptcy. Under the Bankruptcy Code, the term "estate" refers to all of the pre-bankruptcy corporation's property and interests in property. ${ }^{89}$ Thus, at its simplest level, the duty to maximize the estate equates to a duty to maximize the value of all of the corporation's assets for the benefit of shareholders and creditors as a whole, without regard to the distributional

everyone must participate.

82. These negotiations generally revolve around the formation of a plan of reorganization. See 11 U.S.C. $\S$ 1123 (1988) (contents of a plan). The plan provides the financial structure of the reorganized entity as well as other provisions that will govern the company as it emerges from the protection of the bankruptcy proceedings.

83. Since the enactment of the Bankruptcy Code, the general rule is that pre-bankruptcy managers will stay in control of the business through the fictitious entity known as the "debtor in possession." The U.S. Code defines a "debtor in possession" as being the "debtor" unless a trustee has been appointed. The "debtor" is the entity that is the subject of the bankruptcy case. 11 U.S.C. $\S 101(12)$. For most purposes, the debtor in possession can be regarded simply as the pre-bankruptcy corporation with special rights and obligations under the Bankruptcy Code. See N.L.R.B. v. Bildisco \& Bildisco, 465 U.S. 513, 528 (1984); Raymond T. Nimmer \& Richard B. Feinberg, Chapter 11 Business Governance: Fiduciary Duties, Business Judgment, Trustees and Exclusivity, 6 BANKR. DEV. J. 1, 20-37 (1989).

84. See Christopher W. Frost, The Theory, Reality and Pragmatism of Corporate Governance in Bankruptcy, 72 AM. BANKR. L. REV. 103, 156 (1998).

85. See Commodity Futures Trading Comm'n v. Weintraub, 471 U.S. 343, 355 (1985) (stating that "the fiduciary duty of the trustee nuns to shareholders as well as to creditors"); In re Schepps Food Store, 160 B.R. 792, 797 (Bankr. S.D. Tex. 1993) ("A trustee's constituency . . . is broadened under the Code to include not only the debtor and its shareholders, but also all of the debtor's creditors.").

86. See LaSalle Nat'l Bank v. Perelman, 82 F. Supp. 2d 279, 293 (D. Del. 2000) ("Officers and directors should have broad latitude to balance competing interests in a bankruptcy case in order to make decisions that are in the best interests of the estate."); In re Big Rivers Elec. Corp., 233 B.R. 726, 734 (Bankr. W.D. Ky. 1998) ("It is beyond dispute that a Chapter 11 DIP owes a fiduciary duty to all of the creditors and other interest holders of its bankruptcy estate to maximize the value of the bankruptcy estate.").

87. See In re Cent. Ice Cream, 836 F.2d 1068, 1072 (7th Cir. 1988) (stating that a trustee's duty is "to maximize the value of the estate, not of a particular group of claimants").

88. See supra notes 63-67 and accompanying text.

89. 11 U.S.C. $\S 541$ (a) (1988). 
outcome. Employees and other non-investor constituencies may benefit from decisions in the bankruptcy process but the Bankruptcy Code does not require, or perhaps even permit, the bankruptcy judge to consider the effect of managerial decisions on these constituencies. ${ }^{90}$

The Seventh Circuit's analysis in Matter of Central Ice Cream ${ }^{91}$ provides an illustration of managers' duties in Chapter 11. In that case, shareholders of the debtor appealed an order of the bankruptcy court approving a settlement of litigation between the debtor and a third party. The creditors favored the settlement because it was sufficient to pay their claims in full. The district court affirmed the order and sanctioned two of the shareholders for challenging the settlement. In its order approving the settlement, the bankruptcy court made clear that it was guided by the best interests of the creditors, stating:

To seek greater return for the shareholders at risk to the creditors would be most unfair. A creditor supplies to a business in return for getting paid an agreed price. A stockholder puts up risk capital as an investment. The creditor's interest is given major consideration because it is fair that creditors who expected and deserved no risk should not now risk losing all in an effort to recover more for investors. ${ }^{92}$

In analyzing the trustee's claim for sanctions, the Seventh Circuit found that the bankruptcy court's analysis of the settlement misstated the duty of the trustee. Rather than protect the creditors from all risk of loss, the court stated, the trustee was under a duty to maximize the value of the estate. What the Seventh Circuit recognized is that, once they were assured that their claims were paid in full, creditors had no incentive to continue to pursue the litigation regardless of the expected value of that option. While it was true that a continued pursuit of the litigation would expose creditors to risk, the risk was parallel to the risk creditors face outside of bankruptcy. ${ }^{93}$

The Central Ice Cream court thus recognized that neither creditor-focused duties nor shareholder-focused duties, will necessarily lead to decisions that maximize the value of the firm as a whole. Shareholders, because they do not bear the full cost of an incorrect decision, would be more inclined to roll the dice in the hope of a jackpot recovery. Creditors, on the other hand, naturally favor any disposition that would result in payment in full, regardless of whether that disposition maximizes the value of the assets. Because the normal contractual processes that mediate these inefficient incentives are restricted in Chapter 11 , courts seek to reach the efficient result directly. ${ }^{94}$

90. See Christopher W. Frost, Bankruptcy Redistributive Policies and the Limits of the Judicial Process, 74 N.C. L. REV. 75 (1995).

91. In re Cent. Ice Cream, 836 F.2d at 1068

92. Id. at 1070 (quoting In re Cent. Ice Cream Co., 59 B.R. 476, 487 (Bankr. N.D. Ill. 1985)).

93. Id. at 1072 .

94. Although a close examination of the bankruptcy process leads to the conclusion that managers should focus on the maximization of asset value, courts occasionally employ rhetoric that suggests a more creditorfocused duty. For example, where a firm is clearly insolvent, courts often state that the interests of shareholders must be subordinated to the interests of creditors. Commodity Futures Trading Comm'n v. Weintraub, 471 U.S. 343, 355 (1985). This statement does not mean, however, that the courts are employing a creditor maximization principal. Instead, the subordination of shareholder interests in insolvent estates is entirely consistent with the norm of firm value maximization. Requiring managers to consider the interests of out of the money 
The duty to maximize the value of the estate is built into the structure and purpose of the bankruptcy process. Chapter 11 is premised on the idea that a negotiated resolution of financial distress will lead to value maximizing decisions regarding the assets of the firm. To further this idea, the Code provides a forum for collective negotiation which makes possible the capture of going concern value that might otherwise be lost in a liquidation. ${ }^{95}$ Throughout the process, the push and pull of shareholders and creditors is evident as the parties and the bankruptcy judge wrestle with such questions as whether and when to sell assets, to assume or reject executory contracts, to settle claims, and, perhaps most importantly, to appoint a trustee or convert the case to a liquidation under Chapter 7. Most of the bankruptcy decisions on these types of issues depict a bankruptcy judge who is aware of the differing incentives of shareholders and creditors and who seeks a decision that will maximize the value of the assets.

\section{PRESCRIPTION}

Our positive conclusions are that, outside of the bankruptcy context, the law generally obligates corporate managers in normal periods to act in the best interests of shareholders. Delaware case law, however, requires corporate managers in the vicinity of insolvency to act in the best interests of the corporation as a whole, and in insolvency to act in the best interests of creditors.

We find this regime to be ambiguous, confusing, and inefficient and urge Delaware courts to reconsider the matter. We also strongly urge other states to reject this regime. The regime is in our minds an example of the all too frequent mess that Delaware courts

shareholders would lead to an overinvestment in risky projects (such as the continuation of a business that would have more value in liquidation) that would be fundamentally inconsistent with value maximization. Courts that formulate the duty as one owed to both shareholders and creditors are then left to explain why shareholder interests and desires in clearly insolvent corporations are disregarded. See id. The Weintraub Court undertook this explanation as follows:

In cases in which it is clear that the estate is not large enough to cover any shareholder claims, the trustee's exercise of the corporation's attorney-client privilege will benefit only creditors, but there is nothing anomalous in this result; rather it is in keeping with the hierarchy of interests created by the bankruptcy laws.

Id.

A related area of confusion arises where managers take actions in bankruptcy cases that are designed to increase shareholder returns solely at the expense of creditor returns. Tenn.-Fla. Partners v. First Union Nat'l Bank, 229 B.R. 720 (W.D. Tenn. 1999) provides an example. In that case, the debtor's managers failed to disclose several pre-confirmation bids for the assets of the partnership, an apartment property. The creditors complained that the debtor's managers held off several bidders on the property during negotiations that resulted in a plan of reorganization. After a plan was confirmed that resulted in a $75 \%$ recovery to the secured bondholders, the debtor sold the property for almost $\$ 12.5$ million, an amount that would have resulted in the bondholders being paid in full. Id. at 736 . By failing to disclose the interest of the buyers, the debtor succeeded in reducing the creditors claims and to recover the $25 \%$ reduction for the equity holders.

The debtor attempted to justify its actions by claiming that, as debtor in possession, it owed a duty to both creditors and equity holders and that its actions were an attempt to recognize both of those interests. The court made short work of this argument, stating, "Even ignoring TFP's failure to account for its fiduciary duty to the court, the court finds that TFP's failure to maximize the value of the estate was a breach of its fiduciary duty." Id.

95. See Christopher W. Frost, Running the Asylum: Governance Problems in Bankruptcy Reorganizations, 34 ARIZ. L. REV. 89 (1992). 
make of fiduciary duties.

The rule that managers must act in the best interests of shareholders and that nonshareholders must rely on contracts for their protections generally leads to efficient outcomes. ${ }^{96}$ It seems likely that if shareholders (owners) and managers (agents) were able to bargain with one another the shareholders would be willing to purchase some level of fairness and due care from their managers. Non-shareholder constituencies in most cases can be expected either to price the risk that managers' actions may be deleterious to their best interests or mitigate or eliminate such risks through contract provisions.

The filing of a bankruptcy petition, however, prompts a change in the legal landscape that makes a shift in fiduciary duties appropriate. The automatic stay that the Bankruptcy Code imposes effectively precludes creditors from exercising nonbankruptcy contractual remedies. The right to declare a breach and withdraw capital from a corporation when managers violate contractual protections is anathema to the collective nature of the bankruptcy process. In place of those remedies, the Chapter 11 process substitutes a system of managerial duties to the "estate," specific voting rights, creditor representation, judicial supervision, and judicial approval of specific managerial decisions to control the behavior of managers.

Bankruptcy also has the benefit of providing a bright line standard for the shift in managers' duties that the credit markets need to price risk efficiently. Prior to bankruptcy, under Delaware law, shareholders, lenders and others cannot determine ex ante when a shift in duty might arise. These constituencies never know precisely when managers will be permitted, or required, to look out for their interests. As a consequence, creditors may undervalue the protection Delaware law provides, while shareholders may over-estimate the cost that creditor protection imposes on them. Shifting duties only on bankruptcy provides clarity that should increase efficiency in pricing.

This Part offers a closer look at the justifications underlying the shareholder wealth maximization principle and develops the argument against the approach the Delaware courts have taken to fiduciary duties as corporations approach and enter a state of insolvency.

\section{A. The Normative Justifications for Shareholder Wealth Maximization}

As stated earlier, the shareholder wealth maximization norm has a long history in corporate law and is the dominant approach used by courts. In most cases we believe that shareholder wealth maximization leads to efficient results. We recognize, however, that some scholars have attacked shareholder wealth maximization normatively - arguing that it is not an attractive goal-and positively-arguing that it does not adequately describe today's law. ${ }^{97}$

This Article does not make a strong claim that shareholder wealth maximization is the best or even the most efficient approach to corporate governance issues. ${ }^{98}$ Instead we

96. See infra notes $98,111-118$ and accompanying text.

97. See supra notes $1,6,19 \& 21$ (listing scholarly works in this area).

98. The authors are not in complete agreement on the question. Campbell has argued in favor of expanding the beneficiaries of corporate managers' fiduciary duties to include non-shareholder constituencies. See, e.g., Rutheford B. Campbell, Jr., Corporate Fiduciary Principles for the Post-Contractarian Era, 23 FLA. 
take the model as a given and focus principally on the effect that a shift in fiduciary duties has on the financial markets and the parties ability to price risk. Notwithstanding this focus, some understanding of the normative underpinnings of the shareholder wealth maximization principle is necessary to an understanding of the reasons for and against shifting those duties.

\section{Criterion for Efficiency Analyses of Corporate Governance Regimes}

The basic criterion for analysis of the efficiency of any corporate law or regulation is whether the law or regulation in question tends to lead the parties to maximize the value of the corporate enterprise. From this starting point, corporate law makes the general assumption that the parties with capital and other inputs to the corporation have the proper set of incentives to bargain for the governance regime that maximizes the overall value of the corporate enterprise. Rather than directly regulate corporate actions, therefore, corporate law generally establishes a set of mandatory and default rules that may be explained as mimicking the bargain that fully informed and rational parties would choose for themselves. ${ }^{99}$

\section{Shareholder Wealth Maximization and the Efficiency Criterion}

The shareholder wealth maximization criterion takes its normative basis from the idea that the equity ownership in the firm stands as a market-based proxy for societal wealth maximization, because shareholders hold the residual claim on the firm's assets. When a firm is solvent, and is likely to remain solvent, shareholders' gains and losses are usually in lockstep with the value of the firm. Thus when the firm's managers maximize shareholder gains, they are also maximizing the value of the assets under their control. Fiduciary duties therefore serve the purpose of focusing discretionary managerial decision making on maximizing asset value. 100 On this view, fiduciary duties are "gap fillers" in the relationship between shareholders, as owners of the corporation's assets, and managers-reducing the transaction costs and agency problems inherent in the separation of ownership from control. ${ }^{101}$

ST. U. L. REV. 561 (1996). Frost believes that the non-bankruptcy judicial process is not well suited to evaluate managers' decision making on the basis of corporate wealth maximization or any other regime that requires a court to balance the benefits and losses a particular decision imposes on diverse constituencies. Accordingly, Frost favors a regime that points managers in one clear direction with a robust regulatory and contract regime that provides specific protection to other constituencies. Frost, supra note 90.

99. See Gregory Scott Crespi, Rethinking Corporate Fiduciary Duties: The Inefficiency of the Shareholder Primacy Norm, 55 SMU L. REV. 141, 142 (2002) (approaching the efficiency question by asking, "[W]hich assignment of duties ... more closely replicates the jointly wealth-maximizing structure of rights and duties to which rational bargainers establishing a corporation would agree to in costless negotiations?").

100. See Lin, supra note 49 , at 1497 ("[R]equiring directors to maximize shareholder interest provides a fairly accurate benchmark for maximizing the long-term, wealth-producing capacity of the firm.").

101. Jonathan R. Macey, An Economic Analysis of the Various Rationales for Making Shareholders the Exclusive Beneficiaries of Corporate Fiduciary Duties, 21 STETSON L. REV. 23, 26-29 (1991); Crespi, supra note 99 , at $141-42$.

Many situations arise where the proper choices to be made by corporate officials are not completely determined by [contracts between financial claimants and the corporation]. There is an obvious need for courts to impose some principle of accountability to guide those officials in their 
The presence of corporate debt and the accompanying possibility of insolvency skews corporate incentives away from the close relationships between the wealth of the financial investors and the value of the firm, however. Once a corporation issues debt, shareholders have an incentive to over-invest in risky projects, while creditors have an incentive to avoid risk. ${ }^{102}$ Because shareholders, as residual claimants, share the risk of loss with creditors but reap the gains from success, they have an appetite for risk that increases with leverage. Concomitantly, creditors, who bear some of the risk of loss but do not share in gains, would prefer reduced risk. Both shareholders' and creditors' incentives may differ from the investment approach that would maximize the value of the firm. ${ }^{103}$ The conflict is further exacerbated when we take into account the fact that financial investors are not the only stakeholders interested in corporate decision making. Employees, customers, and the surrounding community all contribute to the societal benefits of the corporate form and are all affected by managerial decision making. These stakeholder groups hold incentives that differ from financial investors, and some scholars have argued forcefully that managers should be permitted to take their interests into account when making decisions on behalf of the corporation. 104

One way of resolving these conflicts is to require managers to maximize the value of corporate assets under their control for the benefit of all interested parties. Several corporate law commentators have argued that corporate value maximization should be the standard by which courts should judge managerial decision making. ${ }^{105}$ The normative appeal of this approach is evident upon review of the basic criterion for wealth maximization. The goal is to maximize societal wealth and, to the extent that no single investor group holds a set of incentives that is consistent with that goal, direct regulation of managerial activities to achieve the goal may be appropriate.

In large part, however, corporate law and commentary has resisted this approach. Instead, the mismatch of incentives among stakeholders is mediated through a nexus of contracts that requires non-shareholder constituencies to fix the parameters of managerial decision making. Creditors, employees, and other interested stakeholders negotiate for specific protection through contract and are further protected through similarly specific laws and regulations. ${ }^{106}$ These protections, ${ }^{107}$ along with the protections provided by

exercise of the often substantial discretion left to them by their incomplete instructions ....

Id.

102. See Barondes, supra note 61 , at 48 ("The theory of the corporate enterprise has long recognized that conflicting incentives are created when a corporation issues debt.").

103. Lin, supra note 49 , at 1496 (noting that "[n]either shareholders nor creditors have the incentive to maximize the value of the insolvent firm").

104. See supra notes $19 \& 21$.

105. See Thomas A. Smith, The Efficient Norm for Corporate Law: A Neotraditional Interpretation of Fiduciary Duty, $98 \mathrm{MICH}$. L. REV. 214, $237-48$ (1999) (arguing that rational investors holding diversified portfolios would agree to a rule that requires managers to maximize the value of the corporation, rather than any particular class of claimants); Crespi, supra note 99, at 152-53 (concluding that the locus of corporate officials' fiduciary duty should be the corporation, rather than shareholders).

106. See infra notes 133-134 and accompanying text.

107. See Crespi, supra note 99, at 141 (noting the conventional view that " $[w]$ hen corporate directors and officers . . . make decisions within the remaining zone of discretion whose boundaries are defined by these contractual provisions, they are regarded as subject to a fiduciary duty to maximize shareholder wealth"). 
fraudulent transfer laws, ${ }^{108}$ set the boundaries for managerial discretion within which managers act for the benefit of shareholders. ${ }^{109}$

Considered as a whole, the fiduciary rules that are applicable in normal or solvent periods usually provide incentives for efficient outcomes. The obligation of corporate managers to maximize the total wealth of the company's shareholders creates an incentive for managers to make efficient investments - in technology, for example - as a way to enhance the profit of the owners of the company. Similarly, a rule that discourages wealth transfers detrimental to shareholders is also efficient. Wealth transfer transactions do not necessarily improve allocative efficiency but do involve transaction costs. For those reasons, such wealth transfer transactions are generally inefficient as an economic matter. ${ }^{110}$

Although generally efficient, these fiduciary rules provide an incentive for inefficient conduct in some cases. Denying other corporate constituencies-perhaps most apparently, creditors - the benefit of fiduciary duty protections may provide managers an incentive to construct inefficient transactions.

An extreme example of an incentive for an inefficient transaction can be built on the basic facts of the old Keebler case. ${ }^{111} \mathrm{~K}$ is the $100 \%$ shareholder of $M$ Corp., which has a

108. See supra note 24 and accompanying text.

109. Proponents of shareholder wealth maximization advance a range of justifications for the approach. Bainbridge, for example, focuses on the "two masters" problem, which posits that a fiduciary serving two masters cannot make principled trade-offs between the two, and the "managerial sin" problem, under which a fiduciary with two masters can play the masters off of one another to the fiduciary's benefit. Stephen N. Bainbridge, In Defense of the Shareholder Wealth Maximization Norm: A Reply to Professor Green, 50 WASH. \& LEE L. REV, 1423, 1435-38 (1993); see also Victor Brudney, Contract and Fiduciary Duty in Corporate Law, 38 B.C. L. REV. 595, 640-65 (1997) (arguing for a "contract based approach that might appropriately protect the public senior security holder against opportunistic behavior by common stockholders"). Macey focuses on the cost of contracting, noting that shareholders are the parties most in need of, and willing to pay for, the benefits of fiduciary duties. See Macey, supra note 101, at 36-39 (arguing that shareholders are the group that most needs the gap-filling protection that fiduciary duties provide).

110. Returning to an example loosely based on Weinberger v. UOP, 457 A.2d. 701 (Del. 1983), assume that a merger of a majority owned subsidiary into its parent creates no efficiencies, but instead is driven only by the wealth transfer from minority shareholders to majority shareholders. Such a transaction does not improve allocative efficiency but does involve transaction costs. It is, therefore, an inefficient transaction as an economic matter. On economic grounds, such transactions should be discouraged. Under another approach, some may also wish to discourage such transactions on the grounds of unfairness, since such wealth transfer transactions generate uncompensated losers (e.g., minority shareholders are not compensated for losses they suffer in the value of their investments).

Even when wealth transfers are imbedded in transactions that otherwise move assets into hands that are more efficient, allowing such transactions may nonetheless create incentives for inefficient outcomes. Consider the following example. Imagine that Target Co.'s common stock is selling for $\$ 10$ and that Aggressor $A$ and Aggressor $B$ are bidding for Target's stock. Aggressor $A$ values Target's net assets at $\$ 15$ and the opportunity to expropriate value from other constituencies at \$10. Aggressor $B$ values Target's net assets at \$18 but is unable or unwilling to expropriate any value from other constituencies, and thus values that opportunity at \$0. Aggressor $A$, who values Target's assets less, will likely be the successful bidder for Target's stock, since it can pay up to $\$ 25$, while Aggressor $B$, the one who values the net assets more, can pay only $\$ 18$. The outcome, which is fueled by expropriation, is once again inefficient. Accordingly, today's corporate fiduciary rules, which condemn the managerial facilitation of wealth transfer transactions without regard to whether total shareholder value as a whole is increased, are sound.

111. Swinney v. Keebler Co., 329 F. Supp. 216 (D.S.C. 1971), rev'd on other grounds, 480 F.2d 573 (4th Cir. 1973). 
significant amount of debentures outstanding. $K$ sells all its $M$ Corp. stock to $A$ Corp., which then loots the assets of $M$ Corp., thus rendering $M$ Corp. unable to meet its obligation to its debenture-holders. The claim in Keebler was that $K$, the selling shareholder, breached a fiduciary duty to its debenture-holders by failing to investigate the bona fides of the purchaser, $A$ Corp. ${ }^{112}$ To deny creditors-here, debenture-holdersfiduciary duty protection in such a case may provide an incentive for the sole shareholder to sell to an inefficient looter. A looter may be able to pay the highest price for the company, even though the looter is not the most efficient utilizer of the company's assets, because the looter can recognize the value of the owner's interest in the assets and expropriate creditors' interests by theft. ${ }^{113}$

A less extreme and more typical example of situations in which today's fiduciary duty rules provide an incentive for an inefficient transaction involves a highly leveraged acquisition of the type described earlier. ${ }^{114}$ The power of shareholders to expropriate value from other constituencies-most apparently, creditors-can provide a powerful incentive for transactions that do not improve allocative efficiency. ${ }^{115}$

Beyond the possible allocative inefficiency that can result from such highly leveraged acquisitions and spin offs, ${ }^{116}$ such transactions may raise distributive or fairness issues in the minds of some. Redistributing creditor wealth to shareholderseven if accompanied by improved allocative efficiency-may seem unfair and distasteful to many and thus not the type of transaction that society should sanction.

Creditors, however, are not without protections from such expropriative transactions. For example, fraudulent conveyance statutes protect creditors. ${ }^{117}$ Creditors

112. The district court in Keebler held that Keebler violated a fiduciary duty owed to debenture-holders by selling to a corporate looter. Id. at 224 . While courts have extended fiduciary or fiduciary-like protections to creditors, such cases should be considered aberrations of the widely held view that no fiduciary duty is owed by corporate managers to the corporation's creditors. See supra notes 5, 20 and accompanying text.

113. An example may be helpful. Assume that $M$ Corp. in the hands of $K$ has assets totaling $\$ 100$, represented by $\$ 50$ in debentures and $\$ 50$ in market value stock. The most efficient legitimate bidder may value the assets at $\$ 110$ and thus be willing to pay $\$ 60$ for K's stock. An inefficient looter, however, may be able to bid $\$ 70$ for K's stock, since the looter intends to steal all of M Corp.'s assets and sell them for $\$ 80$.

114. See supra notes 25-27 and accompanying text.

115. Assume that the value of Target's assets in the hands of its old managers amounts to $\$ 100$, which represents $\$ 50$ equity and $\$ 50$ debt. A transaction in which the assets are moved into the hands of less efficient managers - assume the new managers can only manage the assets in a way that generates value of $\$ 90$ - can nonetheless benefit the equity owners, if, for example, the value of their interests goes to $\$ 60$ and the value of creditors' interests goes to $\$ 30$. If the managers' interests are aligned with the owners', managers have an incentive to facilitate this inefficient transaction.

Although structured as a spin off, the reorganization of Marriot in the 1990 s provides an example of a transaction that may have been driven solely by expropriation and thus was not efficient. In the reorganization, Marriot split itself into two separate companies. One of the new companies owned its profitable hotel management business, and the other retained Marriot's real property and its debt. When the reorganization was announced, the value of the stock of Marriot increased significantly, and the value of its bonds decreased significantly. Bondholders in total, however, apparently lost more than shareholders gained. For an excellent brief description of the Marriot transaction see WILLIAM W. BRATTON, CORPORATE FINANCE: CASES AND MATERIALS 238 (5th ed. 2002) ("[a]ccording to Parrino. . . , the bondholders losses incident to the Marriot spin off were not ... equaled . . by stockholder gains") (quoting Robert Parrino, Spinoffs and Wealth Transfers: The Marriott Case, 43 J. FIN. ECON. 241 (1997)).

116. See supra note 26 (describing the transactions).

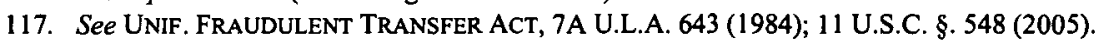


also can protect themselves by ex ante contracting. A poison pill that is triggered by a significant increase in the company's debt is an example of such a protective provision. Alternatively, creditors can extract ex ante compensation for the risk by demanding a higher interest rate to pay for the possibility of future losses due to an increase in the company's debt.

High transaction costs, however, may create a seam within which it is impossible for some creditors to protect themselves by contract. Small or involuntary corporate creditors are perhaps the best examples of corporate constituencies unable to protect themselves by ex ante contract from expropriative moves by shareholders and corporate managers. ${ }^{118}$

Today's fiduciary duties, which deny fiduciary protections to creditors, may be understood to represent a decision by society that, on balance, the risk of inefficient and expropriative transactions are best handled by contract and discrete societal rules, such as the rules that forbid fraudulent conveyances. While some may not agree with that determination and consequently argue that the seam described in the immediately preceding paragraph is broad and thus capable of generating significant amounts of inefficient and expropriative conduct, the clear and long standing rule of societymanifested in such decisions as Metropolitan Life ${ }^{119}$ and Katz ${ }^{120}$-is that the best way to deal with the risk is by contract and discrete rules. In economic terms, society seems to believe that the benefits from any remedy of the problem are less than the costs of the remedy.

While a normative debate over the proper approach continues, positive corporate law seems squarely focused on shareholder wealth as the predominant goal of fiduciary duties. ${ }^{121}$ As described above, inefficient transactions and uncompensated losses are possible within this regime, but society seemingly has determined that the cost of eliminating the possible inefficient and unfair transactions exceeds the benefits of eliminating the transactions. ${ }^{122}$ In short, society seems satisfied that fiduciary duties are efficient for shareholders and managers and that non-shareholder constituencies are efficiently able to construct and price the protections that they desire or need by contractual provisions.

\section{B. Fiduciary Duties in and near Insolvency}

As discussed in Part II, courts have applied a confusing array of standards to judge the behavior of managers of insolvent or nearly insolvent firms. The following discussion examines and challenges the normative underpinnings for the shift of duty upon financial distress and makes the case for maintaining the shareholder wealth maximization norm

118. See Jonathan C. Lipson, Directors' Duties to Creditors: Power Imbalance and the Financially Distressed Corporation, 50 UCLA L. REV. 1189, 1193 (2003) (arguing that creditors that have high levels of "volition, cognition, and exit ... should be limited to the contractual rights they have (probably laboriously) negotiated"). Lipson identifies other creditors with "low levels of volition, cognition and exit ... [that] should benefit from some sort of fiduciary duty from directors of the distressed corporation . . ." He identifies these creditors as "tort creditors," "certain terminated employees," "taxing authorities," and "certain trade creditors." Id. at 1245 .

119. Metro. Life Ins. Co. v. RJR Nabisco, Inc., 716 F. Supp. 1504 (S.D.N.Y. 1989).

120. Katz v. Oak Indus., Inc., 508 A.2d 873, 879 (Del. Ch. 1986).

121. See supra notes 17-39 and accompanying text.

122. See supra note 118 and accompanying text. 
throughout the decline of the corporation until the point at which a Chapter 11 case is instituted.

\section{Normative Justifications for the Shift of Duty upon and in the Vicinity of Insolvency}

The normative case for shifting the focus of managers' fiduciary duties away from shareholders and toward the corporation or creditors upon or near insolvency rests on a claim that the deterioration of the company's financial status enhances the incentives, and the power, of shareholders to expropriate value from creditors. ${ }^{123}$ In its simplest form, this claim is based on the notion that insolvency marks a shift in residual claimants. The standard story posits that upon insolvency, shareholders lose their economic stake in the enterprise and therefore no longer place money at stake in the business decisions. Creditors, on the other hand, now occupy the residual claimant position and therefore hold the correct set of incentives to maximize the value of the business. ${ }^{124}$

At first blush, a fiduciary duty regime that adjusts as the corporation passes from financial health to financial distress makes some sense. The vicinity of insolvency cases are grounded on the idea that insolvency is not a singular event that suddenly marks a change in the incentives of the investors. Corporations are not solvent one moment and insolvent the next. Instead, corporations slide toward and into insolvency over time. ${ }^{125}$ To the extent that shareholder wealth maximization is justifiable because shareholders hold the residual claims, the erosion of that residual position would seem correspondingly to erode the justification. One might view solvency and insolvency as two ends of a spectrum with the duty sliding from one constituency to another as the corporation moves

123. See Barondes, supra note 61 , at 49 ("The theory [of the corporate enterprise] predicts that when a corporation is insolvent or on the verge of insolvency, the incentive to pursue risky investment strategies may increase."); Lin, supra note 49, at 1489.

When the corporation is insolvent or at the brink of insolvency, the difference in risk preference between shareholders and creditors is magnified with respect to corporate investment policies. During this period of financial stress, shareholders favor highly risky projects, even if these projects have only a slight chance of generating income large enough to cover the firm's debt and still provide some return to shareholders.

Id.

124. Lipson, supra note 118, at 1192, characterizes the standard account of fiduciary duties as follows: "As the corporation becomes financially distressed, creditors become its residual claimants, and are in a sense subrogated to the rights and privileges of shareholders, who no longer have an economic stake in the corporation." See also Steven Schwarcz, Rethinking a Corporation's Obligation to Creditors, 17 CARDOzo L. REV. 647, 667 (1996):

Creditors of an insolvent corporation, however, not only have a senior right to repayment but they also now have the right, traditionally associated with ownership, to the "upside" in value of the corporate debtor's assets, at least until the corporation regains solvency. This right is similar to a shareholder's right to the equity of a solvent corporation: in economic terms, the creditors have now become the primary residual claimants.

Id. But see Lin, supra note 49, at 1498 (noting that upon or near insolvency, "creditors want management to preserve the assets available to satisfy their claims by investing conservatively and taking minimal risk").

125. See Ramesh K.S. Rao, David Simon Sokolow \& Derek White, Fiduciary Duty a la Lyonnais: An Economic Perspective on Corporate Governance in a Financially-Distressed Firm, 22 J. CORP. L. 53, 72 (1996) ("The fundamental source of creditor weakness for the financially-distressed firm is the increasing risk creditors bear as the firm slides toward insolvency."). 
along the spectrum. ${ }^{126}$

\section{Critique of the Shift in Duties}

Such a justification for the shift in the fiduciary rule applicable in the normal period is, however, highly problematic, since the bases that support the normal rule of denying creditors fiduciary duty protection do not change when a company enters insolvency. Fundamentally, creditors both in and outside insolvent periods have the same risks and have the same tools at their disposal to deal with the risk.

As the following discussion illustrates, the incentives of shareholders and creditors do not undergo a radical shift as a corporation's financial status deteriorates. While conflicts may intensify, the ex ante bargains struck prior to insolvency remain effective to counteract the desire of shareholders to increase risk. In addition, shifting and then reshifting the beneficiaries of corporate managers' fiduciary duties as the corporation moves from solvency into the vicinity of insolvency, and then into actual insolvency, creates a lack of clarity that has pernicious effects on the ability of all parties to bargain for, price and enforce specific contractual protections.

To the extent shareholder wealth maximization makes sense in normal periods, the underlying efficiency justification for the regime does not change prior to the point of bankruptcy. The principal risk for creditors in both normal and insolvent periods is expropriation. The risk is that shareholders, through their managers, will construct transactions that transfer wealth from creditors to shareholders. In both periods, shareholders have an economic incentive and, if left unchecked, the wherewithal to construct such transactions that benefit shareholders at the expense of creditors. ${ }^{127}$

126. See id. at 75 (describing fiduciary duties, and the legal liability resulting therefrom, as shifting from shareholders to creditors as the firm's financial condition worsens); Andrew D. Shaffer, Corporate FiduciaryInsolvent: The Fiduciary Relationship Your Corporate Law Professor (Should Have) Warned Yau About, 8 AM. BANKR. INST. L. REV. 479, 542 (2000) ("[W]hen a corporation nears insolvency . . . a director/officer ought to start thinking more conservatively.").

127. One way to show this is through examples in which assets of corporations are redeployed in a more risky fashion. Assume that in a normal or solvent period the assets of a firm are worth 200 and that the creditors' claims are 100 and the value of the firm's shareholders' interests is 100 . Assume that the firm is able to reinvest all its assets in a project that has a $50 \%$ chance of recognizing value of 400 and a $50 \%$ chance of recognizing value of 0 . Although the expected value of the firm is unchanged-200-the values of the equity and debt are both affected. Under the redeployment, the value of the equity has increased to 150 . That consists of a $50 \%$ probability that shareholders will recognize 300 (400 total value, minus the 100 prior creditors' claim), or 150 , plus a $50 \%$ probability that shareholders will recognize 0 . The value of the creditors' instruments under the redeployment, however, have decreased in value to only 50 . Creditors have a $50 \%$ chance of 100 (their total claim will be paid if the value of the firm goes to 400 ), or 50 , plus a $50 \%$ chance of 0 . (To simplify the example, we are ignoring the fact that the market may value the redeployed assets at less than 200 , due to the increase in volatility risk. If the volatility is due entirely to risk that is unique to the firm, however, some would argue that the market would not demand a premium (or at least not much of a premium) for the increased volatility, since an investor can cheaply eliminate the volatility by holding a diversified investment portfolio. See Richard A. Brealey et al., Principles of Corporate Finance 144-235 (8th ed. 2006) (discussing risk, the capital asset pricing model and criticism of CAPM). Even if the market sets a value of the redeployed assets at less than 200 , however, the point is still made, albeit with somewhat more complicated math.

This same risk of expropriation of creditor value through asset redeployment exists in a period of corporate insolvency. Assume now that the assets of an insolvent firm are invested in a manner that generates a value of 100, that creditors' claims amount to 100 and the value of the firm's shareholders' interests is 0 . Assume that the firm reinvests its asset in a project with a $50 \%$ chance of amounting to 200 in value and $50 \%$ 
Thomas Smith has convincingly demonstrated that the presence of debt in a capital structure always carries with it a mismatch of incentives between shareholders and creditors that may, depending on the available investments, lead managers to maximize shareholder wealth at the expense of creditors. In fact, given an investment opportunity of sufficient risk, Smith asserts that, even in solvent firms, shareholder wealth maximization might result in inefficient investments that maximize the value of the shareholders' interests while reducing the overall value of the corporation. ${ }^{128}$ Thus, as Smith shows, the basic problem that Chancellor Allen confronted in Credit Lyonnais affects all corporations. ${ }^{129}$ The question is simply a matter of degree. ${ }^{130}$

Although the purpose of Smith's project is to challenge the efficiency of the shareholder wealth maximization norm in solvent companies, his conclusions also support the idea that financial distress does not provide a justification to change the status quo. In fact, history may even suggest that creditors are actually more vulnerable to wealth transfer transactions in normal or solvent periods than they are in periods of insolvency, making it somewhat ironic that courts would choose to enhance creditor protection in periods of insolvency. One might recall, in that regard, that the most notorious and seemingly the largest concentration of expropriation of creditor wealth may have occurred outside of insolvent periods. Specifically we refer to the expropriation of shareholder wealth that occurred in the highly leveraged acquisitions of the 1980s. Notwithstanding the number of such expropriative transactions ${ }^{131}$ and the staggeringly large estimates of the total value of creditors' losses in such transactions, ${ }^{132}$ society chose

chance of amounting to 0 . Although the total value of the firm remains at 100 following the redeployment of the assets, creditor value decreases from 100 to 50 , while shareholders' value increases from 0 to 50 . Creditors' value may be described as a $50 \%$ probability of recognizing 100 and a $50 \%$ probability of recognizing 0 . Shareholders' value may be described as a 50\% chance of recognizing 100 (200 less the 100 in creditors' claims) and a $50 \%$ chance of recognizing 0.

These rather tedious examples demonstrate that in both insolvency and normal periods, shareholders and their surrogates-corporate managers-have fundamentally the same economic incentives to engage in transactions that expropriate creditor value.

128. Smith, supra note 105, at 221-23; see also Campbell, supra note 1, at 460-69 (demonstrating that in solvent periods, gains by shareholders can result from either increased efficiencies, expropriation, or both).

129. Smith, supra note 105 , at 223-24.

130. In Smith's view, the incentive for shareholders of distressed firms to make investments that are socially inefficient "has to do with the firm being in the vicinity of insolvency only in a trivial sense. It is just that the closer to insolvency a firm is, the less risky a bet has to be for its loss to push the firm into bankruptcy." Id.; see also Crespi, supra note 99, at 147 (Investments outside of the vicinity of insolvency "can also result in expected shareholder wealth effects that diverge from expected corporation wealth effects.").

131. See, e.g., Thomas R. Hurst \& Larry J. McGuinness, The Corporation, The Bondholder and Fiduciary Duties, 10 J.L. \& COM. 187, 190 n.14 (1991) (reporting that between 1984 and 1989, 230 companies were involved in transactions that resulted in downgrading of credit rating); see also Marcel Kahan \& Michael Klausner, Antitakeover Provisions in Bonds: Bondholder Protection or Management Entrenchment?, 40 UCLA L. REV. 931, 933 n.2 (1993) (reporting that from 1984 though 1988, 183 companies lost value in their bonds due to acquisitions or LBOs).

132. See Morey W. McDaniel, Bondholders and Stockholders, 13 J. CoRP. L. 205, 206 (1988) (referring to bondholder losses during this period as "possibly the largest expropriation of investors in American business history"); see also Kahan \& Klausner, supra note 131, at 933 (describing acquisitions and LBOs of the period as transforming "blue-chip bonds valued in the tens of billions of dollars into speculative-grade "junk"). The RJR Nabisco acquisition alone was estimated to create $\$ 40$ million in bondholder losses. James Stemgold, Kohlberg Leads Latest Nabisco Bids, N.Y. TIMES, Nov. 30, 1988, at D1. On the RJR acquisition, see generally Deborah A. DeMott, Introduction-The Biggest Deal Ever, 1989 DUKE L.J. 1. 
not to impose fiduciary duties running in favor of creditors injured by such transactions but chose instead to continue to expect creditors during normal periods to bargain for their own protections. ${ }^{133}$

In addition, creditors have the same tool available to protect themselves from such transactions, whether the transactions occur in the normal period or the period of insolvency. The protective tool is the ex ante contract, and creditors can use it with equal effectiveness against transactions in either period. Well crafted financial covenants in debt instruments can accomplish two goals. First, they can prohibit transactions that unduly increase the risk that the corporation will become insolvent in the first instance. Negative covenants prohibiting dividends, additional debt, substantial capital acquisition or divestiture, or a change in business may restrict managers who seek to increase the risk creditors of a solvent business face. In addition, financial covenants may also define default in a way that permits creditors to exercise default and acceleration rights upon the corporation's failure to meet certain financial targets. Net worth covenants, for example, not only guard against transactions that reduce corporate value, but they also give rise to a right to call a default, thereby permitting a creditor to withdraw capital or take control when the financial status of the corporation deteriorates through normal market forces. ${ }^{134}$ There is no reason to assume that creditors are less able through ex ante bargaining to protect themselves from actions that may take place in insolvency than in normal periods.

Thus, there appears to be little reason to justify a shift from shareholder wealth maximization to creditor or corporate wealth maximization when a corporation becomes distressed. The shift creates confusion for managers seeking to determine the standards by which their behavior will be judged. More significant, however, is the difficulty such a shift in duty creates for financial markets seeking to negotiate and price creditor protections. A poorly defined, constantly shifting focus for managerial duties does not provide a stable backdrop for bargaining. How much contractual protection creditors need is a function of how much protection the law provides. It is difficult to negotiate specific covenants when there is uncertainty regarding the default rules that define managers' obligations. By the same token, how much risk creditors face is a function of how the law defines the legal obligation of managers to protect them. Without an understanding of the risk of a particular investment, one cannot set an appropriate interest rate.

In short, the shifting and ambiguous regimes created by the Delaware courts cause difficulties in pricing and allocating the risk of loss among the constituencies. Transaction costs increase, and unintended outcomes seem more likely. ${ }^{135}$

133. See, e.g., Metro. Life Ins. Co. v. RJR Nabisco, Inc., 716 F. Supp. 1504 (S.D.N.Y. 1989).

134. In a sense, these financial covenants may operate to shift control of the corporate assets from shareholders to creditors when the corporation reaches a contractually defined "vicinity of insolvency." The failure to achieve financial targets results in an immediate right to payment, or failing that, a right to take control of the assets through bankruptcy or non-bankruptcy debt collection processes. Although creditors may not exercise these control rights directly, they may use the leverage these rights provide to negotiate an increase in control through additional restrictive covenants, creditor-initiated management changes, and changes in executive compensation. See Stuart C. Gilson \& Michael R. Vetsuypens, Creditor Control in Financially Distressed Firms: Empirical Evidence, 72 WASH U. L.Q. 1005 (1994).

135. In all likelihood, the ambiguity created by the shifting duties will cause creditors to undervalue the protection that the duties provide. Creditors can never be certain when managers will undertake a duty to look out for their interests. Shareholders, on the other hand, are likely to overvalue the cost that the shift in duties 
By contrast, a constant regime with defined duties facilitates efficient pricing and allocation of risk of loss by corporate investors. Creditors in a constant regime realize when they price their capital and accept an investment contract and an interest rate that managers are obligated in all periods prior to bankruptcy to take actions that benefit shareholders at their expense. Consistency in the application of this principle allows creditors ex ante efficiently either to demand more interest for the risk or require covenants to protect them across the entire time spectrum. It facilitates efficient contracting and allocation of losses. ${ }^{136}$

Finally, the ambiguous regime creates opportunities for management misbehavior by rendering enforcement difficult. As Bainbridge has pointed out, "[d]irectors who are responsible to everyone are accountable to no one." 137 A regime that permits shifting duties may allow managers to pursue their own interests, justifying their actions by pointing to a duty to one or another constituency. Confusion over the precise nature of the duty at various stages of financial distress only exacerbates the problem.

Thus, not only is a shift in duties unnecessary, it has negative effects on both the ex ante bargain struck by shareholders, creditors, and managers and on the enforcement of those duties. Maintaining a constant set of duties regardless of the financial status of the corporation permits the efficient allocation of risk and the effective enforcement of managers' duties.

\section{The Exception: Manager Fiduciary Duties in Bankruptcy}

Once the firm enters bankruptcy, a shift away from a shareholder wealth maximization regime to a regime that requires the managers of the debtor to maximize the overall value of the estate for the benefit of both shareholders and creditors makes sense. Non-shareholder constituencies - principally creditors-are unable to protect themselves from actions in this period through ex ante contracting. Also, this single shift does not unduly complicate ex ante contracting and pricing. Rather, the financial contracting process can account specifically for the shift in duties that bankruptcy imposes and can build in provisions that make that shift in duties more likely. Finally, the judicial supervision that characterizes the bankruptcy process reduces the enforcement problems that a duty to multiple constituencies outside of the confines of bankruptcy might generate.

This shift in managers' duties recognizes the changes that bankruptcy imposes on the governance of the firm. Outside of bankruptcy, the efficiency argument for fiduciary duties to shareholders depends on the fact that creditors can draft contracts that will prevent inefficient expropriations of creditor wealth. ${ }^{138}$ In bankruptcy, however, the automatic stay prohibits creditors from enforcing their debt contracts and taking control of the corporation. Thus, continuing to adhere to a requirement that managers act

imposes on them, assuming that managers will seek to protect creditors at the first available opportunity. Such a distortion can only be remedied by clear, easily enforceable rules.

136. See Ted Janger, Crystals and Mud in Bankruptcy Law: Judicial Competence and Statutory Design, 43 ARIZ. L. REV. 559, 581 (2001) ("Crystalline rules minimize judicial discretion, clarify property boundaries, and shift resource allocation decisions out of court and into the market place.").

137. Stephen M. Bainbridge, Much Ado about Little? Directors' Fiduciary Duties in the Vicinity of Insolvency, J. BUS. \& TECH. (forthcoming 2007).

138. See supra notes 106-109 and accompanying text. 
exclusively for shareholders would promote inefficient use of corporate assets.

Unchecked, shareholders' incentive to forestall liquidation regardless of whether liquidation would maximize the value of the corporation would lead to inefficient results. Shareholders of insolvent companies have nothing to lose by delaying liquidation, but would gain if reorganization produces enough value to pay creditors. Thus, managers acting on their behalf might use the bankruptcy process strategically and inefficiently to prolong the reorganization efforts in an attempt to extract concessions from the creditors. ${ }^{139}$

At the same time, as several commentators have pointed out, ${ }^{140}$ requiring managers to maximize the value of creditor claims can create inefficiencies in the opposite direction. Because creditors bear most of the losses of failed reorganization attempts, but have to share the gains from successful reorganizations with the shareholders, creditors may have an incentive to inefficiently cut off promising reorganization efforts. ${ }^{141}$

The bankruptcy process avoids both of these problems by requiring managers to focus on the value of the estate, rather than the value of any particular interest in the estate. In this way, the bankruptcy process prohibits inefficient managerial decisions that transfer wealth between classes of financial investors.

This single shift in duties also has the advantage of providing a bright line standard that creditors and shareholders can account for in their investment contracts. By eliminating the confusion surrounding the timing of the shift, creditors and shareholders can price the risk of their investments based on the assumption that the law will impose an obligation on managers to maximize shareholder wealth outside of bankruptcy and to maximize the overall value of the corporation during bankruptcy. Not only does this clarity provide for better pricing, but it also provides a baseline against which more specific covenants can be crafted.

The shift in managers' fiduciary duties from the shareholders to the estate provides

139. Consider, for example, a corporation in bankruptcy with debts of $\$ 80$ and a liquidation value of $\$ 70$. Assume that the corporation has a $50 \%$ chance of reorganizing successfully with a value of $\$ 100$. If the reorganization fails, however, the assets will be worth only $\$ 20$.

An attempt at reorganization here would be inefficient, resulting in an expected value of $\$ 60(0.5(100)$ $+0.5(20)=60)$ instead of the $\$ 70$ value of a present liquidation. Shareholders, however, would opt for the reorganization. This is because the expected value to the shareholders of the reorganization is $\$ 10$, while the expected value of the liquidation option is zero. The $\$ 10$ value to shareholders $(0.5(20)=10)$ comes at the expense of creditors who would value this investment at only $\$ 50(0.5(80)+0.5(20)=50)$. Managers who are bound to act in the best interests of shareholders would use every means at their disposal to insure that the reorganization option is pursued, notwithstanding the fact that the effort results in the net loss of $\$ 10$ and an expropriation from creditors of $\$ 10$ with no efficiency gains. For a similar example, see Lin, supra note 49 , at $1495-96$.

140. See Chaver \& Fried, supra note 49, at 1823; Lin, supra note 49, at 1492-93; Lipson, supra note 118, at 1225.

141. Assume now that the reorganization efforts chance of success is $80 \%$, but the asset values remain the same. This increased chance of success would render the effort to reorganize efficient, with an expected value of $\$ 84(0.8(100)+0.2(20)=84)$. Because this value exceeds the present liquidation value of the corporation, the reorganization is the efficient choice. Of course, shareholders would agree that the reorganization should be attempted. The expected value of this reorganization to the shareholders is $\$ 16(0.8(20)=16)$. If, however, managers are directed to act in the best interests of the creditors, the reorganization will not be pursued because the effort would result in an expected value to the creditors of $\$ 68(0.8(80)+0.2(20)=68)-\$ 2$ less than the value they expect on liquidation. For a similar example, see Chaver \& Fried, supra note 49, at 1823 ex. 3. 
only a partial response to these inefficient investment incentives, however. In addition, judicial oversight of specific decisions as well as provisions to replace managers with a bankruptcy trustee provide a mechanism that helps to assure that managers fulfill their duties to maximize the value of the assets under their control. ${ }^{142}$ This close supervision by the bankruptcy judge thus ameliorates the enforcement problems that inhere in any system that divides managerial loyalties among naturally adverse constituencies. ${ }^{143}$

The performance of the bankruptcy process in meeting the goal of asset value maximization has been the subject of a vigorous scholarly debate for nearly two decades. Bankruptcy scholarship throughout the late 1980 s and early 1990 s criticized the bankruptcy governance structure as being too heavily skewed toward shareholder interests. ${ }^{144}$ Managers were depicted as maintaining their allegiance to shareholders, taking actions that prolonged the reorganization of firms that should have been liquidated quickly. The bias of managers toward reorganization was seen as an effort on their part to use their continued control over the business to force inefficient wealth transfers from creditor classes to shareholder classes. ${ }^{145}$

More recently, some bankruptcy scholars have detected a shift in the opposite direction. Increasingly sophisticated creditors, particularly secured creditors, employing tools such as debtor in possession financing and management retention agreements, have managed to seize control of the bankruptcy process in some cases-effectively forcing a shift toward creditor value maximization and a bias toward liquidation of healthy companies. ${ }^{146}$ If present, this liquidation bias may create inefficiencies no less troubling than those created by a reorganization bias by prematurely liquidating companies that

142. In fact, several commentators have noted that as a control on managers' behavior, fiduciary duties are much less important in bankruptcy than they are outside of the process. In their empirical study of corporate governance in publicly held corporations, LoPucki and Whitford stated that fiduciary obligations in bankruptcy are largely of "theoretical value" because creditors and shareholders have an opportunity to directly challenge managerial conduct in the reorganization process. Lynn M. LoPucki \& William C. Whitford, Corporate Governance in the Bankruptcy Reorganization of Large, Publicly Held Companies, 141 U. PA. L. REV. 669, 709-10 (1993).

143. See Frost, supra note 95 and accompanying text.

144. See, e.g., Barry E. Adler, Financial and Political Theories of American Corporate Bankruptcy, 45 STAN. L. REV. 311 (1993); Barty E. Adler, Bankruptcy and Risk Allocation, 77 CORNELl L. REV. 439 (1992); Philippe Aghion et al., The Economics of Bankruptcy Reform, 8 J.L. ECON. \& ORG. 523 (1992); Douglas G. Baird, The Uneasy Case for Corporate Reorganizations, 15 J. LEGAL STUD. 127 (1986); Lucian Arye Bebchuk, A New Approach to Corporate Reorganizations, 101 HARV. L. REV. 775 (1988); Michael Bradley \& Michael Rosenzweig, The Untenable Case for Chapter 11, 101 YALE L.J. 1043 (1992); Robert K. Rasmussen, Debtor's Choice: A Menu Approach to Corporate Bankruptcy, 71 TEX. L. REV. 51 (1992); Mark J. Roe, Bankruptcy and Debt: A New Model for Corporate Reorganization, 83 CoLuM. L. REV. 527 (1983); David A. Skeel, Jr., Rethinking the Line Between Corporate Law and Corporate Bankruptcy, 72 TEX. L. REV. 471 (1994).

145. See, e.g., Bradley \& Rosenzweig, supra note 144, at 1076 ("Filing a Chapter 11 petition, in effect, is a way to keep control of the firm free from the intrusive monitoring of creditors, thereby permitting management to extract wealth from the firm's various security holders.") (footnotes omitted).

146. See, e.g., Douglas G. Baird \& Robert K. Rasmussen, Chapter 11 at Twilight, 56 STAN. L. REV. 673 (2003); Douglas G. Baird \& Robert K. Rasmussen, The End of Bankruptcy, 55 STAN L. REV. 751 (2002); George W. Kuney, Hijacking Chapter 11, 21 BANKR. DEV. J. 19 (2004); David A. Skeel, Jr., Creditors' Ball: The "New" New Corporate Governance in Chapter 11, 152 U. PA. L. REV. 917 (2003). Not all commentators are convinced, however. See, e.g., Lynn M. LoPucki, The Nature of the Bankrupt Firm: A Response to Baird and Rasmussen's "The End of Bankrupty," 56 STAN. L. REV. 645 (2003); Stephen J. Lubben, The "New and Improved" Chapter 11, 93 KY. L.J. 839 (2004). 
have a positive going concern value. ${ }^{147}$

Whether these claims of inefficient reorganization or liquidation bias are sustainable is beyond the scope of this Article. If Chapter 11 is dominated by senior secured creditors seeking to use the process to maximize their own recoveries, that fact would provide even more reason to require managers to adhere to a duty to maximize the value of the estate. In addition, as a general matter, bankruptcy judges have shown themselves to be sensitive to the presence of liquidation and reorganization bias and creative in developing techniques to combat them. What remains important for our purposes is the general attitude that the path to efficiency lies in focusing on the value of the assets and in requiring managers to adhere to that focus.

\section{CONCLUSION}

The governance of the modern corporation generally relies on some combination of contractual and fiduciary regulation. As a matter of positive law, the governance rules applicable to solvent corporations obligate managers to fulfill their fiduciary duty to maximize shareholder wealth. Creditors and other constituencies must seek protection through contract. Although the rule itself is controversial, it at least has the virtue of providing clarity for managers seeking to fulfill their duties, for courts evaluating managers' actions, and, most importantly, for investors seeking to negotiate contracts and price their investments.

Recent judicial decisions that attempt to articulate a shift in that duty as a corporation becomes financially distressed have thrown this straightforward rule into chaos. Courts have failed to formulate clear standards regarding both the timing of the shift and the ultimate beneficiaries of the duties at the particular stages of financial decline. As a result, the clarity that permits efficient contracting is lost.

This state of affairs is both unfortunate and unnecessary. Nothing about insolvency, per se, dictates that a separate set of rules should govern the relationship among shareholders, creditors, and managers. In fact, creditor contracts are fashioned with insolvency in mind. Restrictive covenants and the definition of default under creditor contracts contemplate that the corporation's financial status can change and these provisions often are structured in a way to permit creditors to exercise more control over the assets when a company becomes financially distressed. The initiation of a bankruptcy case provides the only point at which these obligations should shift.

147. See Jay Lawrence Westbrook, The Control of Wealth in Bankruptcy, 82 TEX. L. REV. 795, 844 (2004) ("[C]reditor control risks realization of substantially less than the full value of the asset being sold."); see also Lubben, supra note 146, at 856 (discussing the difficulties the creditor control model presents in sorting good (efficient) cases from bad (inefficient) ones). Baird and Rasmussen, however, contest the idea that creditor control leads to inefficient liquidations of firms with going concern value by arguing that fewer firms than most suspect they have positive going concern value. Baird \& Rasmussen, The End of Bankruptcy, supra note 146, at 758 . 